\section{Dansk register}

\author{
Loránd-Levente Pálfi*
}

A

Aarhus School of Business $\rightarrow$ Handelshøjskolen i Århus

Abney, S.

determinativfrase-løsningen 15282

abstraktionsproces 28159

acceptabilitetsdomme $2193 \mathrm{f}$

ACUAH 29275

Adam, Jean-Michel

argumentation og reklameretorik

2047

teksttyper 20 20ff, 42ff, 60-67

additionskonstruktioner $\mathbf{1 7} 259 \mathrm{f}$

adjekt 19 116, 2148

adjektiver

attributive

serialisering 15286

spanske 29 290-299

-able/-ible 29297

-ble

typer af betydningstilskriv-

ning $29297 \mathrm{f}$

-oso/-osa $29298 \mathrm{f}$

adverbialer

ledsætninger 320

sætnings- og fokusteori 13 273-276

adverbialtemaer 3 40-42

adverbier

modificering af substantiver 29296

spanske $29294 \mathrm{f}$

ækvivalens 3180 (def), 180f

overført 15266

* Loránd-Levente Pálfi

Center for Leksikografi

Handelshøjskolen i Århus, Aarhus Universitet

Fuglesangs Allé 4

DK-8210 Århus V

llp@asb.dk

Hermes - Journal of Language and Communication Studies no 39-2007

\author{
afærese 356 \\ afbildningsrum (=fiktionsrum) 26 \\ 139, 30135 \\ afferens 14152 \\ affikser \\ dublet- 355,58 \\ pseudo- 358 \\ affiksoider 358 \\ afledning $\rightarrow$ derivation \\ agens \\ abstrakt $337 \mathrm{f}$ \\ og passiv 168 \\ agent 19 115-129, 116 (def) \\ Ahrenberg, Lars \\ vidensrepræsentation 13305 \\ Ahrenkilde Hansen, Pia \\ europæisk integration/identitet \\ 13346 \\ aktantielle baninger 19 119-122 \\ aktantielle veje 19 119-122 \\ aktionsartsverber 35230 \\ aktiv-passiv-teori 26156 \\ aktivitetsverber $\mathbf{3 5}$ 215, 231 \\ Aktzeit 30151 (def) \\ Albertsen, Leif L. \\ oversættelsesproblemer 18207 \\ tysk fonetik 15273 \\ Albretsen, Jørgen \\ DK87 1236 \\ Alexa 308 \\ alfabetisering \\ af polyleksikalske syntagmer 25 \\ 173-175 \\ se også sorteringsprincipper \\ almenbegreber 3 100-104, 106f, \\ 15188 \\ almensprog 15293 (def)
}


vs fagsprog 3 75-91, 75 (fig), 4 87ff, 15 182-184 (fig), 28161

Almind, Richard

DK87 1234

alordbøger 268 (def), 13292 (def)

Alwood, Jens

talesprogsforskning 13357

Ambjørn, Lone

computermediet og sprogindlæring $309 \mathrm{f}$

American Heritage Dictionary of

the English Language

brugerkommission 2199

informanter $\mathbf{1} 13$

Ammann, $\mathrm{H}$.

tema-rema 13258

anaforer 331

direkte 331

indirekte 331

anaforisk reference 491

analyseregel 18

Andersen, Anton

Dansk-tysk ordbog (Munk) 10

133-141

Andersen, Bjarne H.

surveys i lingvistikken 27 201-209

Andersen, Harry

Dansk Begrebsordbog 18231

Andersen, Øivin

begrebshierarkier 13305

terminologi og tekstanalyse 22192

Andersson, Erik

svensk sætningslære 12 184f

Anglo-amerikansk/dansk retsordbog

$256 \mathrm{ff}$

Anglo-Scandinavian Law Dictionary

of Legal Terms 2 55ff

anisomorfisme, leksikalsk 286

anmelderi 19 133-146, 185-187,

189-194, 201-203, 205

anmeldelsen 19133 (def)

ekstenter 19136

etik $19180 \mathrm{f}$

Wiegands ti etiske bud $19180 \mathrm{f}$ fagbogsanmeldelsen i dagspressen

19 147-156

faktorer 19 195-200

funktion $19172 \mathrm{f}$

Galberg Jacobsen

kritik af 19133

genstand $19174 \mathrm{f}$

i Hermes 19 169-181

danske ordbogsanmeldelser 19

$177 \mathrm{f}$

konstituenter 19136

metode 19 178-180

intentionalkritisk 19 134-136

komparationskritisk 19136

tekstkritisk 19136

de ti metodiske bud 19 179f

nyttesløshed? 19174

objektivitet 19 175-177

politikker

ved lingvistiske tidsskrifter 19

159-168

i Hermes 19181

reaktion på $19176 \mathrm{f}$

Stray Jørgensen

kritik af 19133

teori og praksis $19131 \mathrm{f}$

typer af 19173

anmodninger 3 232-235, 233 (def)

direkte 3235

høflighed i 3 219-244

indirekte 3234

anmodningskontinuum 3241 (fig)

anomalier 28162

Anscombre, Jean-Claude

argumentativ tekstsammenhæng

$189 \mathrm{ff}$

operatorer 2132

teorien om argumentation i

sproget 2121

ansigt 3225 (def), 225f, 14 223,

26123 (def), $27145 \mathrm{ff}$

begrebet 14 223, 15 210f, 26123

D- 15211

I- 15211

interpersonelt 26123 
negativt vs positivt $3225 \mathrm{f}$

personelt 26123

se også face; høflighed

ansigtstruende handlinger $3226 \mathrm{f}$,

14223

anskuelsesrum (=evidentialisrum)

26 139, 30136

antonymi 2197

apokope 356

Apokryfiske bøger 525

Appel, Vibeke

kommatering 13324

syntaksen i H.C. Andersens

eventyr 18 205f

appelfunktion (reklamens) 2158

appellativer 26121

appositioner

attributive 15287

frie 15287

Araus, M.L.G.

spanske verber 17 251-255

Arboe, Torben

fraseologi og dialekt 35154

argumentation 1 89ff, 14 245-248,

2122

funktorer 21 16, 29-36

inferenslove $191 \mathrm{f}$

og konnektion i sproget 21 155f

operatorer 190

program 1 93-95

ræsonneren 2122

og reklameretorik $2047 \mathrm{f}$

retning $14162 \mathrm{f}$

sammenhængslove $192 \mathrm{f}$

sammenkædningslove $190 \mathrm{f}$

semantik 2117

tekstsammenhæng 1 89-93

teorien om argumentation $\mathrm{i}$

sproget 21 21-24

verbets argumenter 2149 (def)

argumentationsanalyse 21 15-36

analyseniveauer $2117 \mathrm{f}$

modulær tilgang 21 18-21

moduler 2119

argumentativisme, radikal 2121 argumentativitet 2122

argumenter

eksterne 1169 (def)

interne 1169 (def)

argumentrelationer $\mathbf{1} 74$

argumentstruktur 21 47-51

Aristoteles $\mathbf{2 8}$ 157f

indflydelse på klassisk terminolo-

gi 28 158-160

tema-rema 13258

ARK (skriftserien) 15179

arketypegrafer 19115

Arndt, Hans

sproget 33 193-195

artes liberales 1 130f

artes mechanicae 1 130f

ARTHUS 29274

artikler

delings- $20267 \mathrm{f}$

italiensk

artikelbrug 20265

artikelsyntaks 20 264-269

nul- 15286

Arutjunow, A.R.

semantisk valens 173

aspekt $2155 \mathrm{f}$

assimilation 160

association

vs flytning 27 114-120

asyndese $\mathbf{3}$ 22-26

Atkins, Sue

korporas repræsentativitet $\mathbf{1 5} 248 \mathrm{f}$

Atomica 3081

atomisme, logisk 28160

attunement $\mathbf{1 4} 171$

Auður Hauksdóttir

dansk-islandsk fraseologi 35155

Aurelius, Eva H.

genreteori 20235

Austin, John L.

sproghandlinger 5114

vellykkethedsbetingelser 5 114f, 120

autonomibegrebet 3030 (def)

autopoiesis $28165 f$ 
autorisationsprincipper 1 169-172 VP- 1 171f

Axelsen, Jens

Engelsk-dansk ordbog 23 221-230

Institutionsnavne dansk-engelsk

29 263-268

B

Baaring, Inge tolkning 11 147-153

Bach, Svend

italiensk grammatik 6 175-179

Baden, Helge

Medicinsk ordbog 14 267-271

Bahr, Joachim

korporas repræsentativitet 1231

Baldinger, Kurt

fagsprog 381

Bally, Ch.

champ associatif 288

Balsgart, Karin

fagordbøger 11117

kritik af Genteknologisk ordbog

11 117-121

Bandwurmwörter 834

Bang, Jørgen

Omvendt fremmedordbog 10143 -

154

Barber, Charles L.

tempusformer i fagsprogstekster 312

Barik, Henri C.

simultantolkning 3 185, 187

Baron, Irene

dansk og fransk retskultur 36185

navne for overbegreber i fransk

35214

Barthes, Roland

retorik 13371

Barwise, J.

semantisk relativisme 2142

basislemma 264 (def)

basisrum $26138 \mathrm{f}$
Bausch, K.R.

teksttypologisering 2162

Bazerman, Charles

fagsprogsforskning 2187

$\mathrm{BBC}$

tekstning 13247

BBI Combinatory Dictionary of

English

ordforbindelser og kollokationer

$35106 f$

BDS 29274

Beaugrande, R.-A.

diskursanalyse 2205

kohærens 36160 (def)

kohæsion 36162 (def)

Bedeutung 282 (def), 14151

se også betydning

Beedham, Christopher

passivforskningen 1 69-70

begivenhedsmodel 2081

begreber 3100 (def), 15188 (def),

28 155-176

abstrakte 4121

almen- 3 100-104, 106f, 15188

begrebet $391,100-110$

begrebsdannelse 28 155-176

teknisk 28 184-187

begrebsrække

horisontal 3121

vertikal 3121

benævnelses- 3 102, 104

betydnings- 3 102, 104

definition 3 107-110

del-helhedsrelation 3105 (fig)

ekstension 3103

vs genstand 3 99-101 (fig), 28 184f

genstandsløse 3106

genstandsrelaterede 3106

individual- 3 100-104, 15188

integration 3105

intension 3103

kritikken 28 159f

leksikografisk udmøntning

i Den Danske Idiomordbog 32

212-219 
over-

fransk 35214

reale

vs teoretiske modeller $4116 \mathrm{f}$

tegn- $\mathbf{3} 102$

vs termer $\mathbf{2 8} 158$

terminologisering 28 184-187

vs virkelighed 4 115-121

Behr, Irmtraud nominalgrupper $15281 \mathrm{ff}$

i ytringsenheder uden verbal 15 288

postnominale præpositionalfraser 15284

Béjoint, Henri

definitioner $12161 \mathrm{f}$

belæg 1 16-17

belægsamling vs tekstkorpus 117 , 211

døde sprog 116

believe space $\rightarrow$ evidentialisrum

Bellert, Irena

kohærens 154

benævnelse 3 100-102, 104-107

benævnelsesbegreber 3 102, 104

benævnelsesstrategier $35214 f$

Bergenholtz, Henning

begrebet fordelingsstruktur 21132

Dansk-hollandsk ordbog 20200

Den Danske Ordbog 33 179-191

fagrelaterede ordbogsartikler 1066

fagsprogsforskning 1195

Genteknologisk ordbog 10 79-93,

11 123-129

idiomdefinitioner 32207

IFF Fagordbog 1069

informanter ved ordbogsarbejde

$27207 f$

Juridisk ordbog spansk-dansk 7

109-114

et juridisk tekstkorpus 1210

korporas repræsentativitet 1231

Nordisk leksikografisk ordbok 20

235-242

ordbogsfunktioner tekstrelaterede vs ikke-tekstre-

laterede 21124

ordforbindelser og kollokationer

35106

Regnskabsordbogen dansk-

engelsk 34 279-283

retskultur $36191 \mathrm{ff}$

sprogpolitik 31 167-170

synopseartikler 21132

Bergenholtz, Inger

Politikens Musikordbog 20 242-244

Bergenholtz, John

DK87 1236

Berglund, L.O.

reklamer 2153

Bergstrøm-Nielsen, Henrik

Dansk-tysk ordbog (Munk) 10

133-141

Bernhardt, Lise

indirekte gengivelser 30147

bestemmelser 14171

betegnelsesenhed 3105

Betrachtzeit 30151 (def)

betragtningstidspunkt 30151

betydning 2 97ff, 193ff, 3 101, 13

252-255, 253 (def), 253 (fig), 254

(def), 14 150, 15 293, 29 33-51

Bedeutung 282 (def), 14151

begrebet 2 82-92, 83 (fig)

betydningsmæssig underbe-

stemthed 29 44-47

désignation $283 \mathrm{f}$

establishment of senses 2195

hierarki 29 39-41

kommunikeret mening $2941 \mathrm{f}$

ords vigtige/mindre vigtige 23

190 (fig)

integration af 23191 (fig)

relationen mellem tegn og 399 -

101 (fig)

sense modulation 2195

sense/reference 283

signifikation 2 83f, 13253 (def),

253 (fig), 254 (def)

Sinn 282 (def), 14151 
-kontinuität 36160 sproglig vs ikke-sproglig 299 udelelig $2936 \mathrm{f}$ udtryk vs indhold 29 33-35 betydningsbegreber 3 102, 104 bevægelsesverber 35212 bevingede ord 32 216-218 Bibelen $\rightarrow$ Apokryfiske bøger; Biblia Hebraica Stuttgartensia; Christian III's Bibel; Christian IV's Bibel; Christian VI's Bibel; Codex Leningradensis; Dødehavsteksterne; Guldalderbibelen; Lutherbibelen; Septuaginta; Vulgata; Zürcherbibelen

bibeloversættelse 5 15-33 dansk

historie 5 17-20

problemer 5 15-33

privat 519

den resen-svanningske $518 \mathrm{f}$

Biber, D.

genrer 22195

Biblia Hebraica Stuttgartensia 526

Bidstrup, Ulla

oversættelse 16 221-223

billardkuglemodel 2081

billedlighed

ved idiomer 3678

Bilmes, Jack

konversationsanalyse 20145

bindingsteorien 1 180-184

Bisgaard, Jonna

sprogpolitik 31 167-170

Bislev, Sven

europæisk integration/identitet $\mathbf{1 3}$ 347

Blaaberg, Hanne

Forretningssprog. Engelsk-Tysk-

Fransk 12 192-195

Blake, Barry J.

agent 19116

locus-rollen 19117

blended learning 3057 (def)
Boel, Lisbeth

DK87 1234

bogstavparkonkordans 137

bogstavrim 35154

Bohr, Niels

komplementære beskrivelser 28168

Boisson, Claude

regnestok-eksemplet 20270

Boivineau, J.

reklameoversættere 2154

Bonhomme, Marc

argumentation og reklameretorik 2047

Booth, Wayne

metaforforskere 29302

Bork, Ernst

Tysk-dansk ordbog (Gyld) 11

155-159

Boström, Lena

læringsstile 3067

Boye, Jette

ordbøger

brugervejledning vs indledning

21128

forord 21129

Boysen, Gerhard

fransk grammatik 11 133-142

brachygrafi

leksikalsk $356 \mathrm{f}$

syntagmatisk 363

brancheordbøger 16 267-274, 269

(def)

definitioner 16272

fagsystematik 16 271f

flerordsforbindelser $16272 \mathrm{f}$

grammatiske oplysninger 16273

illustrationer 16272

lemmaselektion 16 270f

Brandt, Jørgen Gustava

bibeloversættelse 524

Bréal, Michel

neologismer $1102 \mathrm{f}$

Bresson, D.

højreudvidelserne i NP 15283 
Brink, Lars

fraseologiterminologi i DK 35 155

Briz, Antonio

diskursmarkøren o sea 29274

Brottier, O.D. de

adjektiver på-able/-ible 29297

broverbumsfænomener 2 21-26, 30

Brown, P.

høflighedsteori 15211

Brown-Corpus $1231 \mathrm{f}$

Brügger, Niels

strukturalisme 31 211-213

brugstekstanalyse 20 255-259

Brunse, Niels

litterær oversættelse 15 265f

Bruun, Erik

Dansk Sprogbrug. En Stil- og

Konstruktionsordbog 16 223-225

Budin, Gerhard

terminologi og videnskabsteori 22192

Bühler, Karl

sprogfunktioner 1202

Buhl, F.

bibeloversættelse 519

Bullinger, D.H.

reklamers uoversættelighed 2 151f

bundstyring 14199

Burger, Harald

fraseologi 17266

idiomer i ordbogsartikler 25174 182

Buscha, Joachim

hovedstrukturytringer $\mathbf{3 0} 151$

Business Leksikon

anmeldelse 29 247-260

Bytinget 14 245-247

\section{C}

c-commandklausulen 27114

$\mathrm{CAL} \rightarrow$ computer assisted learning

CALL 3013

Cantell, Ilse
Nordisk leksikografisk ordbok 20

235-242

Cartagena, Nelson

orddannelse i fagsprog 29275

Casafont, M.L.

adjektiver i spansk $29298 \mathrm{f}$

Cassirer, Peter

retorikkens historie $20244 \mathrm{f}$

CCCA 20145

CCSARP-projektet 14 192, 194-196

Center for Leksikografi 20 181-187

Chafe, Wallace L.

tale vs skrift 6191

champ associatif 288

Charaudeaus, Patrick

diskursgenrer 2 165f

Charolles, Michel

kritik af isotopibegrebet 1 53f, $59 \mathrm{f}$

reformulering 14148

Chomsky, Noam

bindingsprincipper 1159

Burzios generalisation 215

flytning 27 114, 119

fokusdomænets struktur $\mathbf{1 3} 265$

I-sprog og E-sprog 233

interpretation 155

kasusteori 1172

korpusskepsis 1229

syntaktiske strukturer 17106

systemkritik 13367

X-bar syntaks 1160

Christensen, B.W.

Dansk-Engelsk Handelsfaglig

Ordbog $1070 f$

Christensen, Johnny

Lettisk-dansk/dansk-lettisk

grundordbog 16 225-228

Christensen, Lotte W.

korpuslingvistik og terminologi

22191

Christensen, Marianne

Dansk-hollandsk ordbog 20200

Christensen, Robert Z.

dansk grammatik for svenskere $24184 \mathrm{f}$ 
Christian III's Bibel 5 17f

Christian IV's Bibel 518

Christian VI's Bibel 5 18f

Christoffersen, Jonas

europæisk retskultur 36181

retlig kreolisering 36 186, 195

Chuwku, Uzoma

eponymer 20270

informatikterminologi 12162

Cicero, Marcus Tullius erhverv

romernes opfattelse 21148

citatagtige fraser 3599

Clark, Richard E.

medier $\mathbf{3 0} 13$

Clitau, Thomas Christensen

Et lidet Orthografisk Lexikon kritik af 19134

Cobler, Paul

kultur 28186 (def)

Codex Leningradensis $526 \mathrm{f}$

Cohérelle 20 80ff

Coltier, D.

reformulering 14148

Combinatory Dictionary of Medical

English Usage 20 195-198

Common European Framework of

Reference 30 40-43

computer assisted learning 3057 (def)

Confais, J.-P.

nulkasus og ikke-markering 15288

constraints 14171

contextual selection 2195

CORDE 29269

opbygning $29275 \mathrm{f}$

Cortés, C.

nominelle konstruktioner 15284

Coseriu, Eugenio

betydning 299

Linguistik des Sinns 15292

Coulmas, Florian

rutineformler 18159 (def)

counterfactuals $\rightarrow$ irrealt rum

CP

vs TopP 27 127-132
Cramer, Jens

dansk grammatik for svenskere

$26168 \mathrm{f}$

CREA 29269

opbygning $29275 \mathrm{f}$

Cristofoli, Mirella

fraseologiske somatismer 35157

cross-talk model 14200

CRTT

præsentation 12 159-163

Cruse, D.A.

betydning 290

leksikalsk semantik 2 193-200

CTN

præsentation 12 163f

Cuff, E.C.

diskursanalyse $2208 \mathrm{f}$

culturally contexted conversation

analysis $\rightarrow$ CCCA

CVB 29273

cykliske princip, det 1 176-180

D

D-strukturer 1 158ff

Dagrin, Bengt G.

Stora fula ordboken $23232 \mathrm{f}$

Dahlberg, Ingetraut

abstraktionsproces 28159

Dairy Vocabulary

vs Landbrug/levnedsmiddel

Ordbog (L\&H) 1076

Dalum, Ane

organisationsanalyse 34 154f

Dam, Helle

Juridisk ordbog spansk-dansk 7

109-114

Danell, Karl J.

lingvistik 15 245-253

Danes, $\mathrm{F}$.

tematisk progression 333

DANFRAS 35 153-159

danismer

i ordbøger 25 190f

Danlex-gruppen 
tekstkorpora 1234

Danmarks Radio

sprogpolitik 31 144-146

tekstning 13 236, 248

dansk

-faget efter 196814250

i EF 13 310-318

engelsk indflydelse 16 238-241,

21 194-198, 26 190-194

flerordsenheder 35 156f

fagsproglige komposita 8 32-35

forhandlinger

mexikanske/danske

turn-taking i taleenheder 20149

fraseologi

dansk-islandsk 35155

dansk-japansk 35158

dansk-tysk $35155 f$

fraseologiske somatismer

$\mathrm{i}$ italiensk, fransk og dansk 35157

fremmedord $15261 \mathrm{f}$

grammatik

for svenskere 24 184f, 26 168f

vs italiensk

uoversættelige ord $\mathbf{1 5} 256$

konjunktiv 17146

modalverber 1 133-150

passiv 1 63-82

passiverbarhed 1 63-82

litteratur om 170

præference for kortsyntagmer 340

purisme 15 261f, 26191

IT-sprog 5147

retskultur

vs fransk 36185

rigsmål vs særsprog 12197

sætningsstruktur

vs spansk 3 29-49

sprogrigtighedsspørgsmål 12

196-198

spørgsmål og svar

vs italiensk 19 29-50

sproghistorie $14250 \mathrm{f}$

turopbygning

vs tyrkisk 20149
Dansk Begrebsordbog

kritik 18231

Dansk Eksportleksikon 29 247, 251

Dansk Jagtleksikon 20249

dansk radiærordbog 1 37-41, 41 (fig)

Dansk Sprogbrug. En Stil- og

Konstruktionsordbog

anmeldelse 16 223-225

Dansk Sprognævn

Den Danske Sproglov 29 198-200

immuniseringsstrategi 29212

manglende reverens for 33187

overtrædelse af loven 29 199ff,

31 160-163

Retskrivningsordbogen 2195

retskrivningsvejledning

kritik af 31 160-163

Dansk-Engelsk Fagordbog (L\&H)

10 69-71

se også Teknisk Ordbog (L\&H)

Dansk-engelsk handels- og

fagordbog (Baileys) 2 55ff, 10 68f

Dansk-Engelsk Handelsfaglig

Ordbog $1070 f$

Dansk-Engelsk Handelsordbog $1070 \mathrm{f}$

Dansk-engelsk ordbog (Gyld)

komposita $838 \mathrm{ff}$

Dansk-engelsk ordbog (V/B)

anmeldelse 7 123-128

komposita $838 \mathrm{ff}$

vs L\&H Teknisk Ordbog 9 199-203

Dansk-engelsk ordbog. Undervis-

ning 12209

Dansk-engelsk teknisk ordbog

(Clau) 16267

vs L\&H Teknisk Ordbog 9 198-204

Dansk-engelsk teknisk ordbog

(Warrern)

layout 4 33-35

Dansk-fransk marketing ordbog anmeldelse 8 111-126

Dansk-fransk ordbog $(\mathrm{B} / \mathrm{H})$

fraseforrådet 35 162ff

layout 436

Dansk-fransk ordbog (Gyld) 
vs Forretningssprog. EngelskTysk-Fransk 12194

Dansk-fransk teknisk ordbog (Clau) anmeldelse 5 143-152

reaktion på anmeldelse $7115 \mathrm{f}$

Dansk-hollandsk ordbog (Gyld) 20

199f

Dansk-italiensk ordbog (Gyld) anmeldelse 15 254-261

Dansk-spansk handelsordbog (Por muchas razones)

anmelderiets nyttesløshed? 19174

bogen trækkes tilbage 19174

Dansk-spansk erhvervs- og

økonomiordbog anmeldelse 7 153-162

Dansk-spansk fagordbog anmeldelse 7 153-162

Dansk-spansk ordbog (Munk) anmeldelse 19 262-267

Dansk-tysk ordbog (Gyld) idiomer $25172 \mathrm{ff}$

layout 4 36-38

Dansk-tysk ordbog (Gads Large) idiomer $25172 \mathrm{ff}$

Dansk-tysk ordbog (Munk) anmeldelse 10 133-141 idiomer 25 172ff

Dansk-tysk ordbog. Undervisning anmeldelse 12 207-210

Dansk-tysk teknisk ordbog (Clau)

1071

anmeldelse 7 139-144

DanskOrdbogen manglende reverens for Dansk Sprognævn 33187

DANTERM 15 187f

Darbelnet, J.

substantivsyntagmer 338

transposition 346

Darmesteter, Arsène neologismer 1102

data 110

dataleksikografi 35115

datalingvistik 5 153-156, 35115 som erhvervssproglig forsk-

ningsgren 5 153-156

Datendistributionsstruktur 21 132,

135

Davidsen-Nielsen, Niels modus og modalitet 1140

purisme 26191

DDO $\rightarrow$ Den Danske Ordbog

Dechert, H.W.

metakognitiv viden $13334 \mathrm{f}$

defaultfokus $13265 f$

defaultlæsning 13254

definiendum 3 108f, 494

definiens 3 108f, 494

defining vocabulary $\rightarrow$ definitions-

vokabular

definit form $36171 \mathrm{f}$

definitioner 2 66, 3 107-110, 494 -

96, 12 161f, 14 158, 161, 163

analytiske 35122

betydningsforklaring leksikografisk 266 (def)

paradigmatisk 20250

syntagmatisk 20250

ekstensionale $3107 \mathrm{f}$

genus/species- 28170

intensionale 3 107f

nominal- 3 113, 28158

vs real- 28158

parafrase

leksikografisk 266 (def)

real- 28 158, 170

terminologiske vs leksikografiske $12161 \mathrm{f}$

udarbejdelse af $28171 \mathrm{f}$

definitionsteori 28 155-176

definitionsvokabular 3313

definitor 3 108f, 17269

Deignan, Alice

ordbog over metaforer $29306 f$

deiksis

som kohæsionsskabende middel

36175

person- 26 120, 36175 
DeKeyser, Robert mekaniske drills 3025

deklarationer 5 114-116

Searles 5115

dekomposition 830

Delbecque, Nicole

kritik af M. Leonetti 29291

spanske NPer 29 291-293

delectare

idiomer 35 147-149

DeMello, George

objekt i spansk 29271

Den Danske Idiomordbog 32 201-234

idiombegrebet

leksikografisk udmøntning 32

212-219

teoretiske problemer 32 213-215

kollokationer 35 111-113

Den Danske Netordbog

vs DDO, NDO og RO $33157 \mathrm{ff}$

kollokationer 35 111-113

manglende reverens for Dansk

Sprognævn 33187

Den Danske Ordbog 33 149-176, 179-191

fleksion og genus 33 189f

genuine formål $33151 \mathrm{f}$

grammatik 33 171-175, 188

kollokationer 35 110f

layout 33 152-154

lemmaselektion 33 155-163,

180-185

vs NET, NDO og RO 33 157ff

omtekst 33 154f

orddannelsesangivelser 33 164-

171, 190f

pseudo-diakrone relationer 33165

ordklasser 33 188f

tilgangsstruktur 33 152-154

denomination 14 158, 161, 163

Der Deutsche Wortschatz nach

Sachgruppen (Dornseiff)

kritik 18231

derivation $354 \mathrm{f}$ bare-, gid-, mon- og sikke-udtryk 27 105-111

parasyntetisk 35

Descartes, René

det udstrakte vs det uudstrakte

2934

désignation $283 \mathrm{f}$

deskription 21100

deskriptiv lingvistik 17 103-112

vs præskriptiv lingvistik 21

101-107

og leksikografisk praksis 21 107-

116

normativ kraft 21109

vs præskription 21 101-107

traditionen 17 105-107

typer af $\mathbf{2 1} 106$

se også normproblematikken;

præskription; proskription; sprogrigtighed; usus imperans; usus imperium; usus tyrannus

deskriptivisme $\rightarrow$ deskription

determinativfraseløsningen $\mathbf{1 5} 282$

determinativfraser

koordinerede 15286

Devons, Ely

tværfaglig forskning 36193

DIALANG 30 40, 51-54

dialektrim 35154

diatese 2155

Diccionario Fraseológico del

Español Moderno

anmeldelse 17 266-268

Diccionario para la enseñanza de

la lengua española

anmeldelse 17 268-272

Dictionary of Anglicisms in Danish

anmeldelse 21 194-198

Dictionary of Dairy Terminology

vs Landbrug/levnedsmiddel

Ordbog (L\&H) 1076

Diderichsen, Paul

sætningsled 17163

Dietrich, Veit

bibeloversættelse 518 
differens 28 165f

differentiering 3021

Dijk, T.A. van

diskursanalyse 2 201-211

makrostrukturteori 26143

mentale rum 30137

ramme 22194 (def)

teksttyper 20 60-67

Diks, Simon

overflade- vs underliggende strukturer 17144

dimension (semanalyse) 295 (def)

diminutiv

spansk $26121 \mathrm{f}$

direktive kommissiver $\mathbf{2 6} 123$

direktiver 5 113, 26 123, 126-128, 133

disambigueringsproblematikken 2195

diskurs 147 (def), 2205 (def), 20

20, 21 (fig)

diskursive strukturer 152

fag- 1 48, 12 99-104

videnskabelig 314 (def)

diskursanalyse 1 45-61, 47 (def), 2

201-211

vs realisme 4 118-120, 119 (fig)

diskursgenrer $2163 \mathrm{ff}$

diskurshandling

vs tekstgenre vs teksttype 2027

(fig)

diskursmarkører

o sea 29274

dissimilation 160

Dittmar, N.

tysk som andetsprog $13335 \mathrm{f}$

DK87 1 229-236

dobbeltformer 11143 (def)

danske 11 143-146

docere

idiomer 35 147-149

Dødehavsteksterne 526

domæne-rum 26139

domæner (semanalyse) 295 (def)

domain space $\rightarrow$ konstitutivt rum

dominansmodellen $2015 \mathrm{f}$

Dornseiff, Franz
Der Deutsche Wortschatz nach

Sachgruppen 18231

domænemetaforer 18232

DP-løsningen 15282

Dressler, W.U.

kohærens 36160 (def)

kohæsion 36162 (def)

driftsøkonomi 21142 (def)

dublet-affikser 358

Dubois, B.L.

fagsprogsforskning 2189

tema 343

Ducrot, Oswald

argumentation i sproget $\mathbf{2 1} 21$

modifikatorer 2133

tekstsammenhæng 1 89ff

Duden. Das große Wörterbuch

der deutschen Sprache

belæg 117

Dunn, K.

læringsstile 3068

Dunn, R.

læringsstile 3068

Dupont, C.

international forhandling 2 189f

Durovic, L'ubomír

slavistikken $6203 \mathrm{f}$

dybdestruktur 1 154ff, 17 144f

Dyrberg, Gunhild

et juridisk tekstkorpus 1210

E

e-learning 30 57-72, 57 (def)

E-sprog 233

ear-voice span units 3185

EDB

symposium om 13 305-309

se også IT

Effort-model 17284

Egebak, Niels

dekonstruktivisme 19 145f

Eggins, S.

sprogbeskrivelse/SFL 24164 
Eiberg, Kristian interkulturel virksomhedsledelse 13342

Eichinger, L.M. adjektiver $15286 \mathrm{f}$ genitivattributter 15283 ekkospørgsmål 217 ekspletive konstruktioner 27 120-124 ekspressiver 26 122, 126-129 ekstension 20 265f (def) Elbeshausen, Hans europæisk integration/identitet $\mathbf{1 3}$ 347

Elbro, Carsten

kommatering 13324

elementærudsagn 3111

ellipser

leksikalske 356

Ellis, Rod sproglæring 3026

ELSAM-projektet $20203 \mathrm{ff}$

emergens 28165

emnehandlinger 13357

EmneLeksikon Basis anmeldelse 13 364-371

Emonds, J.E.

strukturbevarende transformation 1 153ff

empiri 1 7, 4119

empirisk basis $18-10$

i sprogvidenskab metoder 1 7-22

ending politely 27145

endocentrisk konstruktion 5139

Engel, Gert

fagsprogsforskning 1195

engelsk

ESP

kausalitet 3 11-27

fagsproglige komposita 8 32-35 indflydelse på dansk 16 238-241, 21 194-198, 26 190-194

flerordsenheder 35 156f

modalverber 1 133-150

ret 14225
Engelsk-dansk basisordbog lemmatisering af ordforbindelser 18170

Engelsk-dansk ordbog (Gyld) anmeldelse 23 221-230

Engelsk-dansk ordbog (Kjærulff

Nielsen) 1072

vs L\&H Teknisk Ordbog 9 199f

Engelsk-dansk teknisk ordbog

(Clau)

vs L\&H Teknisk Ordbog 9 198-204

Engerer, Volkmar faseverber 2960 (def)

English Law Dictionary 2 56ff

enhedskomma 13 319-326

enhedsvidenskaben 28160

enighedsspørgsmål 19 39f

ensemble de définition 2 89, 94

ensrettere 2135

entailmentstruktur 35216

enten-eller-spørgsmål 1939

enthymem 2045

entiteter 17 156-159, 19 117, 2146

ENTREVIS 29273

epidiktioner 2048

erfaringssprog 2215

erhverv

borgerlige 21 147f

frie $21147 \mathrm{f}$

immaterielle 21147

klassificering 21 147-149

liberale 21147

romernes opfattelse 21148

service- $21148 \mathrm{f}$

tertiære $21148 \mathrm{f}$

Erhvervs- og økonomiordbog anmeldelse 7 147-152

erhvervsøkonomi 21142 (def)

vs nationaløkonomi 21142

erhvervsret 21143 (def)

erhvervssprog 1 193-194, 193

(def), 4 125, 21 139-149

begrebsudredning 21 139-149

danske/tyske betegnelser 21 146f 
sproghistorisk baggrund 21

143-145

vs fagsprog 21 141, 149

erhvervssprogsforskning 1 189-207,

3 281-285, 4 125, 21140

datalingvistik 5 153-156

genstandsområder 1 189-192

vs humanistisk sprogforskning 1

191

i Sovjetunionen 1 197-207

Eriksen, Lars

Tysk-dansk computerordbog med de engelske fagudtryk 27 193-200

Erla Hallsteinsdóttir

Kühns model for frasemindlæring $35153 f$

Erom, H.-W.

nominalnegationer $15285 \mathrm{f}$

$\mathrm{ESP} \rightarrow$ engelsk; fagsprog

essens 28159

establishing credentials $27144 \mathrm{f}$

establishment of senses 2195

ethos 19 272, 34 163f

etnometodologi 20 141-143

etnometodologisk konversationsanalyse 20 139-160

etymologi $\mathbf{3 2} 205$

populær 7 179-181

EU

påvirkning af det danske retssystem 36181

Eurodicautom 3096

Eurogermanistik 15 281f

Europarådets fælles referenceram-

me 30 40-43, 48, 53f

Eurotype-projektet 17108

eventuelt rum (=mulighedsrum) 26

139, 30135

evidentialisrum (=anskuelsesrum)

26 139, 30 136, $145 f$

exercitiver 5114

exocentrisk konstruktion 5139

Eyben, W.E. von

juridisk sprog 4130
Ezquerra, Manuel A.

anvendelsen af para nada 29273

$\mathbf{F}$

Faber, Dorrit

et juridisk tekstkorpus 1210

Fabricius, Johann A.

usus imperium 21103

Fabricius, Julie

anvendt retorik $36219 \mathrm{ff}$

face 3225 (def), 225f, 14 223, 26

123 (def), $27145 \mathrm{ff}$

-begrebet 14 223, 15 210f, 26123

D- 15211

I- 15211

interpersonelt 26123

negativt vs positivt $3225 \mathrm{f}$

personelt 26123

face-threatening acts $\mathbf{3} 226 \mathrm{f}, \mathbf{1 4} 223$

facework 27 147, 150

faceworkstrategier $27150 \mathrm{ff}$

factual absurdity $285 \mathrm{f}$

fællesskandinavisk enhedsstræv 21

100f

Fält, Gunnar

spansk grammatik 27 211f

Fafner, Jørgen

skriftstilistik 16249

fag

-områder 3 87, 4 85f

-viden 14253

og fagsprog 1066

den professionelle verden $\mathbf{1 2} 99$

fagdiskurs 1 48, 12 99-104

fagkommunikation 36193

fagleksikografi 13 292f, 18 157-

172, 29 329ff

dansk jagtsprog 20248

purisme 20248

den fagleksikografiske løsning 29

330-333

det fagleksikografiske problem

$29329 f$

og Intranet/Internet 29 340ff 
koncern- 29 339-347

intranetbaseret 29 339-347

holistisk og socialkonstrukti-

vistisk model 29343 (fig)

vs terminografi $\mathbf{1 3}$ 293, 306-309

vs terminologi 13 306-309, 15

191-193

terminologisk leksikografi 13306

se også alordbøger; brancheord-

bøger; fagordbøger; handelsord-

bøger; juridiske ordbøger; medi-

cinske ordbøger; sagordbøger;

specialordbøger; tekniske ordbøger

fagordbøger 2 137-147, 10 65-93,

11 117-121, 13293

vs almensproglige 5127

Clausens vs L\&H 10 71f

eksempler

oversættelses- 29333

syntaktiske 29334

tekst- 29328

tematiske 29334

unificerende 29 327-336

emneangivelser 10 71-73

emneklassifikation

standard $1072 \mathrm{f}$

encyklopædiske/grammatiske

oplysninger 1068

energi- og miljø

koncernrelateret 20 203-209

fagintroduktioner $\mathbf{1 0} 80, \mathbf{1 4} 268$

i skandinavisk juridisk leksikografi $\mathbf{1 4} 226$

fagsystematik 15193

en genteknologisk ordbog

dansk-cubansk samarbejde om 13 291-303

kollokationer 29328

lemmaselektionen 259

vs tekniske ordbøger 1071

teori til konception af 29 327-336

se også alordbøger; brancheord-

bøger; fagordbøger; handelsord-

bøger; juridiske ordbøger; medi-

cinske ordbøger; sagordbøger; specialordbøger; tekniske ordbø-

ger

fagsprog 1 245-250, 3 79, 89 (def),

497 (def), 8 36f, 10 68, 1299

(def), 14 251-259, 253 (def), 15

182-184, 291 (def), 292 (def)

vs almensprog 3 75-91, 75 (fig),

4 87ff, 15 182-184 (fig), 28161

arbitraritet/nonarbitraritet $\mathbf{1 4} 254 \mathrm{f}$

bastardisering af $\mathbf{1 2} 98$

definitionstyper 3 86-91

vs dialekt 385

dilemmaet 3 74f

engelsk

kausalitet 3 11-27

medicinsk 30 101-128

vs erhvervssprog 21 141, 149

og fag $\mathbf{1 0} 66$

som forskningsdisciplin 3 73-95,

4 85-97

genrenormer 1 246-248

grammatik 10 67f

inddeling af $\mathbf{1 0} 104$

vs almensprog 3 76-78

Ammons sfæremodel 3 82f

analytisk metode $\mathbf{3} 76$

Baldingers model 381 (fig), 81f

Hoffmanns model 383

horisontal inddeling (Wüster)

379 (fig)

onomasiologisk metode 378

Sagers model 3 83-85

semasiologisk metode $377 \mathrm{f}$

syntetisk metode $376 \mathrm{f}$

vertikal inddeling 380 (fig), 80f

IT 3 60-69, 30 75-99

dansk

purisme i 5147

fransk 3 60-69

proveniensen af $\mathbf{3} 65$

metaforer i 23 173-200

jura 5 123-126

teksttypologisk undersøgelse $\mathbf{2 0}$

84-104

kommunikation 10 103-108 
komposita 8 29-42

dansk og engelsk 8 32-35

kritik af $\mathbf{1 5} 198$

kulturbundethed vs -neutralitet 15

196f

medicin

engelsk 30 101-128

metaforer 23 173-200

vs modersmål 385

orddannelse 29275

oversættelse 3 29ff, 12 91-108

vs sagsprog 14254

vs sociolekt 385

tekstsortkonventioner 15 290-293

termen

vs LSP 15183

vs terminologi 3 92-95

se også erhvervssprog; handelssprog; sprog; subsprog; teknisk sprog; teknolekt; terminologi

fagsprogsforskning 1 194f, 2 173-

178, 3 11ff, 4 125f, 14 251f, 260

begyndelsen 14254

bibliografi om 1 195f, 2 128, 7

103-108, 15181

i Danmark 15 179-199

begyndelsen 15181

grammatiske og lingvistiske

arbejder 15 193-196

opgaver og problemstillinger 2 127-131

den funktionalistisk orienterede

$14254 \mathrm{f}$

2nd International Eindhoven

LSP Conference 2 187-191

et kortlægningsprojekt 2 127ff

i Sovjetunionen 1 197-207

vs almensproglig forskning 1198

vs terminologi 15 190f

terminologien 15180

fagtekster

kohærens 1 48, 14 259-266

referens 14 259-266

Fahl, Laurids

Gyldendals, Politikens og Dansk
Sprognævns retskrivningsordbøger $29200 \mathrm{ff}$

faktoranalyseprincippet $\mathbf{3 5} 122$

falsche Freunde 25 187, 189f

falsificering

interpersonel 3113

Fant, Lars

sætningsstruktur

dansk vs spansk 340

Farø, Ken

dansk-tysk fraseologi $35155 f$

Gyldendals, Politikens og Dansk

Sprognævns retskrivningsordbøger

$29200 \mathrm{ff}$

idiomer 3679 (def)

diakron udvikling 35143

idiomatisk indhold 35140

ordsprog 3680,88

variation/modifikation 3681

termen frasem 35136

termen talemåde 35158

faseverber 2960 (def)

semantisk beskrivelse 29 53-69

tidsbetingelse 29 53-69

Faucher, E.

kommaets funktion og betydning

i tysk 15287

Fauconnier, Gilles

mentale rum 26 137f, 30 133ff, $240 f$ rumtyper 26139

Feigs, W.

kompetens og performans $\mathbf{1 3} 338$

Felder, R.M.

læringsstile 3068

felter 287

feltteorien 2 87-89, 103

fememer 1106

femer 1106

Fernández, F.M.

dobbeltrepræsentation af objekter

på spansk 29275

Ferrara, Alessandro

diskursanalyse 2207

Figurenrede 128

figurer 18 220f 
fiktionsrum (=afbildningsrum) 26

139, 30135,144

Fill, Alwin

økolingvistik 14 219-224, 220 (def)

strukturalisme 14221

Fillmore, Charles

diskursanalyse 2204

kasusgrammatik $171 \mathrm{ff}$

nyere og nyeste sprogteori 17104

rammesemantik $22194 \mathrm{f}$

semantiske roller 17155

filosofi

og klassisk terminologisk teori

28 157-162

Findreng, $\AA$

tysk som fremmedsprog 13336

Firbas, Jan

FSP 330

Fjeld, Ruth V.

Nordisk leksikografisk ordbok 20

235-242

fjernkontrol 229

fjernundervisning 3057 (def),

101-128

Fleischer, Wolfgang

fraseologi 17266

leksikografisk kodificering 25199

Florentsen, Peter

oversættelse 18205

flowdiagram 332 (fig)

Fluger, Lena

tolkning 15268

flytning

vs association 27 114-120

fokalisatorer

leksikalske 13269

morfologiske 13269

syntaktiske 13269

fokalisering 13 259-269

typer 13 261-263

fokaliseringsblokering 13264

fokus 13 259-276

default- $13265 f$

identifikation

stærk 13 262, 268 svag 13262

kontrast- $13267 \mathrm{f}$

neutralt 13 261-271

og ordstilling 13 272-276

scope of $\mathbf{1 3} 264$

simpelt 13 261-271

special- 13 261-271

sproglig binding 13 263-266

tema- 13 269-272

Verum- 13267

fokusdomæne 13 263-266

fokusgrupper 31 215-217, 215 (def)

fokusrematisering 342

fokusteori

og sætningsadverbialer 13 273-276

fokustryk 13 267-269, 272

folkelingvistik 36 183, 195

fonetik

tysk 15 272-281

forbindere 14203

forbudsprincippet 31162

fordelingsstruktur (leksikografisk)

21135 (def), 135 (fig)

begrebet 21132

i et brugerorienteret perspektiv 21

121-136

vs henvisningsstruktur $21133 \mathrm{f}$

forholdsnormer 5117

forik $21221 \mathrm{f}$

forikon 21220

forkortelser

franske 16 265f

formalisering

formel leksikalsk repræsentation

2 77-107

formel sprogbeskrivelse 2 78-82

formelle sprog $278 \mathrm{ff}$

formalisme $\mathbf{6} 205$

formidlingsteorien 36193

forretningsbreve

franske

afsluttende bemærkninger i 15

225-234

sluthilsener i 15 207-237 
Forretningssprog. Engelsk-Tysk-

Fransk

anmeldelse 12 192-195

vs Gyldendals røde dansk-fransk og fransk-dansk 12194

forskningspolitik

på handelshøjskoler og universi-

teter 5 7-14

fraktomorfemer $\mathbf{3} 59$

frameanalyse $2163 \mathrm{f}$

frames 1 87, 2 106f, 163, 22 192-

198, 194 (def)

interaktionelle 22195

Frandsen, Finn

DK87 1234

international markedskommuni-

kation 20 245-247

medierne og sproget 19144

Frandsen, Helle Pals

Juridisk ordbog dansk-engelsk

18 208-216

Juridisk ordbog engelsk-dansk

14 225-235, 18169

et juridisk tekstkorpus 1210

Frandsen, Lene

udarbejdelse af definitioner 28171

franglais 353

fransk

forretningsbreve

sluthilsener i 15 207-237

fraseologiske somatismer

i italiensk, fransk og dansk 35157

grammatik 11 133-142

informatikterminologi 3 60-69

proveniensen af $\mathbf{3} 65$

old-

grammatikskrivning 19 69-74

overbegreber

navne for $\mathbf{3 5} 214$

oversættelse

teknisk

fransk-svensk 35 275-279

fransk-tysk 35 275-279

retskultur

vs dansk 36185 teknisk

orddannelse 3 51-71

Fransk-dansk ordbog (Gyld)

vs Forretningssprog. Engelsk-

Tysk-Fransk 12194

Franske forkortelser $12195 f$

frasemer 32 208-210, 210 (def), 35

$135 \mathrm{f}$

dualt koderede 25 172, 175

etords- 35137

kohærens 35 139-142

kompositionalitet 35 138-142

semantisk 35 139-142

udtrykssyntaktisk 35 138f

som konstituenter i løbende tekst

35 135-150

Kühns model for indlæring af $\mathbf{3 5}$

$153 \mathrm{f}$

præsentationsform (i fx ordbøger)

32 220-227

pragmatiske restriktioner 32 228-

230

termen 35 136-138, 158

xeno- 32 206, $215 f$

fraseografi $32201 \mathrm{f}$

meta- 32202

fraseoleksika $32218 \mathrm{f}$

fraseologi $32208 \mathrm{f}$

dansk-islandsk 35155

dansk-japansk 35158

dansk-tysk $35155 \mathrm{f}$

og etymologi 32 205, 35154

grammatisk variation $32226 \mathrm{f}$

vs idiomatik 25172

kollokationer som fraseologisk

kategori 35 97-116

kriterier 17266

leksikalsk variation 32 220-226

den leksikografiske fejlslutning

35156

den leksikologiske fejlslutning 35

156

og oversættelse $35157 f$

spansk 17 266-268

terminologi 
Danmark 35155
forvirring $3597 \mathrm{ff}$

den translatoriske fejlslutning 35

156

se også bevingede ord; falsche

Freunde; idiomatik; kollokatio-

ner; ordsprog; parømiologi; tale-

måder; vendinger

fraseologiforskning

trippel-skizofreni 32211

fraseologiske somatismer

i italiensk, fransk og dansk 35157

fraseonymer 32 216-218

fraseotermer $32215 f$

fraser 35 155, 161-180

bøjningsvarianter 35169

citatagtige 3599

det danske fraseforråds størrelse

35 161-180

del- 35168

faste

polysemi 35120

homonyme

vs homonyme ord 35168

homonymi $35167 \mathrm{f}$

notationsproblemet 35169

polysemi $35167 \mathrm{f}$

prædikative 27 109-111, 109 (def)

unikke elementer 35 179f

ytrings- 35169

fraseringskomma 13321

frasestruktur $1154 \mathrm{ff}$

frasetymologi 32 205, 35154

Frege, Gottlob

begrebets væsen og dannelse 28161

betydning $282 \mathrm{f}$

semantik 2146

semantisk realisme 2141

Freiburger-Korpus 118

frekvens

bogstavpars

i Dansk Retrogradordbog 143

(fig)

relativ af danske enkeltbogstaver 1

$$
\text { 38, } 42 \text { (fig) }
$$

fremmedord 10146 (def)

bekendthedsgrad 10147

i dansk $15261 f$

vs fremmede ord $\mathbf{1 0} 150$

fremmedordbøger

omvendte

tyske og danske 10154

fremmedsprog

kompetenceniveauer 30 39-54

fremmedsprogspædagogik $\rightarrow$ frem-

medsprogsundervisning

fremmedsprogstilegnelse

psykolingvistiske og didaktiske

aspekter 13 332-340

se også sprogindlæring

fremmedsprogsundervisning 14

191-212, 30 39-54

grønlandskfaget på de gymnasiale uddannelser 14 210-212

indlæring af ordforråd 14 192,

197-202

højttænkningsøvelsen 14 198-200

indlæring gennem dybdebear-

bejdning $14201 \mathrm{f}$

lagring af ord i langtidshukommelsen 14 201f

leksikalske gættestrategier $\mathbf{1 4}$

198-201

og IT 30 13-34

nabodiscipliner 14193

pædagogisk udviklingsarbejde $\mathbf{1 4}$

192, 206-209

den skriftlige dimension 14 192,

202-206

sprogfærdighedsniveauer 30 43-45

sprogfærdighedsområder 30 45-47

tværsproglig pragmatik 14 192-197

se også sprogindlæring; sprog-

undervisning

Frosterud, L.G.

Franske forkortelser $12195 f$

Fruchtbringende Gesellschaft 21101

FSP $329 f$ 
teori vedr. sætningens FSP-

signaler 330

fundament $17162 \mathrm{f}$

genstands- 17163

situations- 17163

fundamentpladsen 17 162-166

funktion (syntaks) 5138 (def)

funktionalisme $\mathbf{6} 205$

funktionalstile 1 201-204

makro- 1203 (def)

mega- 1203 (def)

mikro- 1203 (def)

funktionel grammatik 17 107-111, 141-144

funktionel syntaks $\rightarrow$ syntaks

funktionelt sætningsperspektiv $\rightarrow$

FSP

funktionskomma 13322

funktorer, argumentative 21 16,

29-36

fuzzy sets 1 135-136

fyndord 14 279-283

G

Gabrielsen, Gorm

kommunikationsproblemer og retskultur 36184

Gads Lille Leksikon anmeldelse 13 364-371

Gads Tysk Large $\rightarrow$ Tyskdansk/dansk-tysk ordbog (Gad)

Galindo, Orlando

Dansk-spansk erhvervs- og

økonomiordbog 7 153-162

Dansk-spansk fagordbog 7 153-162

Erhvervs- og økonomiordbog 7

147-152

Galinski, Chr.

terminologi og dokumentation 13305

gambitter 14 208, 215 (def), 216

Garde, Anna

Konference om Leksikografi i

Norden 14 236-238
Garfinkel, Harold

etnometodologi 20141

gatekeeper encounters 14 196f

Gaudin, François

terminologiens berettigelse 20270

Gawinski, Birthe

Dansk-spansk ordbog (Munk) 19

262-267

Geertz, Clifford

etnografisk analyse 20 154f

Geist, Uwe

sproglig tekstanalyse 19 268-279

Gelas, Nicholas

hierarkisering af isotopier $152 \mathrm{f}$

kritik af isotopibegrebet $\mathbf{1} 59$

generalisering 14 159f, 164

generalitet

aftagende $\mathbf{1 4} 159$

stigende 14159

generativ grammatik $\mathbf{1 7} 105 \mathrm{f}$

den generative skole 111

passiv 2 9-12

semantik 220

styring 1167 (def), 167f

behørig 1168 (def), 168f

syntaktisk teori 1 153-184, 2 9-33

generics $\rightarrow$ generisk rum

generisk rum 26 139, 30 134, 139f

genitivus explicativus 15283

genre 15 194f, 22 192-198

relationen mellem sprog og 22197

tekst-

vs diskurshandling vs teksttype 2027 (fig)

genreordbøger $29331 \mathrm{f}$

genreteori 20235

genstand 3111

individual- $3105 \mathrm{ff}$

genstandsfundament 17163

Genteknologisk ordbog 10 79-93,

11 123-129

anmeldelse 11 123-129

kritik 10 79-93

replik på anmeldelse $\mathbf{1 1}$ 131f

replik på kritik 11 117-121 
replik på replik 12 183f

genus

fælleskøn og intetkøn

valgfrihed mellem 31162

germanismer 25 186f

Gertsen, Martine C.

interkulturel virksomhedsledelse

13343

Gerver, David

simultantolkning 3 180ff

Gil, Marc O.

spanske tekstkorpora $29271 \mathrm{f}$

Giles, Daniel

Effort-model 17284

Give Kommune

sprogpolitik 31 143f

Givón, Talmy

amerikanske grammatikere 17108

Gluckman, Max

tværfaglig forskning 36193

Gluško, M.M.

fagsprogsforskning $1204 \mathrm{f}$

funktionalstile 1202

Goethe, Johan W. von

det alfabetiske princip 13364

Götselius, Thomas

genreteori 20235

Goffman, E.

face 15 210f, 27145

Goldman-Eisler, Frieda

simultantolkning 3185

Golfkrigsmetaforikken 23198

Google 3080

avanceret søgning 3085

sprogværktøjer 3086

Goosse, André

neologismer $1103 \mathrm{f}$

Gorbatjovtolkning 11149

Gottlieb, Henrik

engelsk indflydelse på dansk

flerordsenheder 35 156f

tekniske tekster $28180 \mathrm{ff}$

tekstning 15268

oversættelse af idiomer $18206 f$
Graae, Gustav

Jagtsproget 20 247-254

Graae, Lisbeth

Jagtsproget 20 247-254

Grabarczyh, P.

fagsprogsforskning 2189

Gradenwitz, Mogens

kommatering 13 319-326

Gramkow, Karsten

lingua franca-samtaler 20148

grammatik 2110 (def), 111 (def),

17 103-112

-genren 6 175-179

-skrivning 17 142-148

-undervisning

forståelsesorienteret $\mathbf{2 9} 188$

vs produktorienteret $29192 \mathrm{f}$

inputbearbejdning $29192 \mathrm{f}$

nye tiltag 29 187-195

begyndere vs fortsættere $2113 \mathrm{f}$

beskrivelsesniveauer og dimensi-

oner 17 139-167

dansk

for svenskere 24 184f, $26168 \mathrm{f}$

definitioner af 2 110-112

den deskriptive tradition 17 105-107

eksempler i en 19 13-26

ordforrådet i 19 17-24

oversættelse af 19 24-26

ekspressiv 2 109-126

fagsprogs- 10 67f

fundament $17162 \mathrm{f}$

funktionel 17 107-111, 141-144

generativ $17105 f$

den generative skole 111

passiv 2 9-12

semantik 220

styring 1167 (def), 167f

behørig 1168 (def), $168 \mathrm{f}$

syntaktisk teori 1 153-184, 2 9-33

grammatisk beskrivelse 2112 (def)

holistisk 29188 (def)

vs systemorienteret 29 188-191

indholdsform 17148 (def)

indholdsstruktur 17 154-158 
indholdssubstans 17148 (def), 154-158

italiensk 6 175-179

konsultations- $6175 \mathrm{f}$

notional grammar 3 11-27

opbygning af en 1 158f

postgymnasial engelskundervis-

ning 2 109-126

produktions- vs receptionsbrug 127

situationsteoretisk 14 167, 185

spansk 29 269-277, 278-284

basis- 7 175-178

sproglig struktur og substans $\mathbf{1 7}$

148-150

sproglige niveauer 17 144-148

sproglige paradigmer 17 151-

154, 161-166

sproglige parametre 17 161-166

den strukturalistiske revolution

17105

svensk $12184 \mathrm{f}$

traditionel 17 105-107, 29188

tysk 16 252-255

se også sprogbeskrivelse

grammatikaliseringsteori 17 107-110

grammatisk komma 13 319-325

Grand Dictionnaire Terminolo-

gique $\mathbf{3 0} 96$

Greenbaum, Sidney

tekstkorpora 117

Greimas, A.J.

isotopier $\mathbf{3 6} 172$

neologismer 1 105ff

ords indhold

teori vedr. strukturering af 1

105-118, 106 (fig)

semantisk isotopi $145 \mathrm{ff}$

definitioner af 1 47ff

Grice, H.P.

konversationsmaksimer 4 92f, 14

222, 15 226, 27165

sproglig økonomi 492

Grimm, Jacob

det alfabetiske princip 13364

ordbøger 21111
Grindsted, Annette

ækvivalenter i oversættelsesord-

bøger 2 217-220

Grinsted, Annelise

fagsprog og erhvervssprog 13305

Genteknologisk ordbog 11 131f

leksikografi og terminologi 15265

Grøn, Hanne

fagsprogsforskning 2 173-178

P. Harms Larsens kritik af

fagsprog 15198

grønlandsk

på de gymnasiale uddannelser 14

210-212

grounding $\mathbf{2 0} 82$

GRSLSS 3067

Grünbaum, Ole

tekno-fetichisme 309

Grundfos

sprogpolitik 31 152-159

Grundtvig, N.F.S.

ordsprog 3679

Gubba, Wilhelm

Juridisk ordbog dansk-tysk 18167

Juridisk ordbog tysk-dansk 18167

Gueintz, Christian

tysk grammatik 21 101f

Guillermo, Rojo

funktionel syntaktisk analyse 5

137-142

Guldalderbibelen 518

Gumperz, John

gatekeeper encounters 14 196f

Gundersen, Dag

fællesskandinavisk enhedsstræv

21 100f

Nordisk leksikografisk ordbok 20

235-242

Gunnarsson, B.

fagsprogsforskning 2 188f

H

Hårbøl, Karl

kommatering 13323 
Omvendt fremmedordbog $\mathbf{1 0}$ 143-154

Haastrup, K.

fremmedsprogspædagogik $14200 f$

Habermas, Jürgen

kommunikation 5116

sproghandlinger 5 115-118

haleeksempler 10135

Halkier, Bente

fokusgrupper 31 215-217

Hall, Edward T.

kommunikation og kultur 20140

kulturanalyse 20152

og interkulturel kommunikation

20152

samfund med forskelligt etos 27159

Hall, Mildred R.

kulturanalyse 20152

Halliday, M.A.K.

endoforisk/exoforisk reference

21155

systemisk funktionel lingvistik

24 161-178, 34144

tekniske begreber 24166

Hammerich, L.L.

tysk fonetik $15272 \mathrm{f}$

Hammerich, Paul

undervisning på engelsk i andre

fag 26193

Hamzé, Hassan

passiv i arabisk 12163

Handelshøjskolen i Århus

metaleksikografisk litteratur 20187

ordbøger $20184 \mathrm{f}$

ph.d.-afhandlinger 20 186f

handelsordbøger

fra Center for Leksikografi 20

189-194

handelssprog

spansk 23 242-244

handlinger

aktuelle $3116 \mathrm{f}$

ansigtstruende $3226 \mathrm{f}$

emne- 13357

illokutionære 3 233, 1939 kommunikative 3 238, 20143

lovgivnings- 5 114, 116

positionelle 3233

potentielle $3116 \mathrm{f}$

struktur 21 56-58

tale- 19 39-41

vellykkethedsbetingelser 5 114f,

120

vise- 3 116f

se også anmodninger; høflighed;

interaktion; sproghandlinger

handlingstidspunktet $\rightarrow$ Aktzeit

handlingsverber 17 254f, 35 215, 231f

Hansen, Aage

passivforskningen 170

Hansen, Camilla S.

registeropskrift 34 157-159

Hansen, Erik

fremmedord i dansk 15 261f

kommaets historie i Danmark 13

319

sprogrigtighedsproblemer 12 196-

198

i stedet for/i steden for? 2198

Hansen, Erik J.

surveys i lingvistikken 27 201-209

Hansen, Johan W.

Dansk-spansk ordbog (Munk) 19

262-267

Hansen, Leo

et juridisk tekstkorpus 1210

Harder, Thomas

litterær oversættelse 18207

Hare Hansen, Jens

fagsproglig kommunikation $\mathbf{1 0}$

103-108

Hasan, R.

systemisk funktionel lingvistik

24 161-178

Haß, Ulrike

eksemplets funktion 18163

Hastrup, Kirsten

etnografisk analyse 20 154f

kultur 20151

tværfaglig forskning 36192 
Haugen, Einar økolingvistik 14220 (def)

Hauschildt, Bent kritik mod terminologilærens grundopfattelse 15 188f

Hausmann, Franz Josef ordbøger ekstensive vs selektive 260 intuitionsbaserede kollokations- 16224

tosprogs-

danske 2217

ordbogskriminalitet 1252

Haven, Niels von Et lidet Orthografisk Lexikon 19 134

Heegård, Jan

Gyldendals, Politikens og Dansk Sprognævns retskrivningsordbøger $29200 \mathrm{ff}$

Hegel, Georg W.F.

bøgers form og indhold 21126

Helbig, Gerhard

hovedstrukturytringernes tidslige indordning $\mathbf{3 0} 151$

passivforskningen 1 67-68

Hellspong, Lennart

brugstekstanalyse 20 255-259

Heltberg, Eva

skrivepædagogik 22 172-175

Henriksen, Berit H.

debatter og dueller 13358

Henriksen, Torben

Juridisk ordbog dansk-tysk 18 168f

Juridisk ordbog spansk-dansk 5

127ff, 7 109-114, 8 133-136

henvisning $\rightarrow$ reference

Hermanns, Fritz

eksempler i ordbøger 18163

Hermes $15 f$

anmeldelser i 19 169-181, 2111

ny anmeldelsespolitik i 19181

Lingvistisk Kollokvium på HHÅ

219

målgruppe 2112
Net- 26 9f, 29 9f

rubrikker i 2111

i sit 11. år 22 9-11

skriftserie 2113

tiårsjubilæum 21 9-13

Herslund, Michael

adjekt 19116

dobbelt lokativ 19126

præpositionsstranding 27118

purisme 26191

semantik $2147 \mathrm{f}$

Hertzka, Alfred 1 67-68

Hesse, Rolf

fraseologi og oversættelse 35 157f

HHÅ $\rightarrow$ Handelshøjskolen i Århus

hilseformularer

sluthilsener

danske 15207

franske

forretningsbreve 15 207-237

hyppige 15 217-220

særlige 15 220-222, $232 \mathrm{f}$

Hjelmblink, Steen

Retsplejeordbog 9 193-196

Hjelmslev, Louis

kommutationsprøven 493

leksikalsk anisomorfisme 286

neologismer 1 104f

teksten 17 145f

Hjørnager Pedersen, V.

eksempler i ordbøger 18164

oversættelse $15262 \mathrm{ff}$

syntaksen i H.C. Andersens

eventyr $18205 f$

Hjort, Katrin E.

europæisk integration og identitet 13347

interkulturel kommunikation $\mathbf{1 3}$

340-348

Hjorth, Grethe

Dansk-tysk ordbog. Undervisning

12 207-210

Hochlautung 15275

høflighed 3 224-227, 14 223, $15210 f$

$i$ anmodninger 3 219-244 
D- $15226 f$

i forretningsreve 15 207-237

I- $15226 f$

$\mathrm{i}$ interkulturel kommunikation 3

227-230

lingvistisk 3219

negativ 3232

positiv 3232

i rykkerskrivelser 15224

strategier 3 226f, 235-237, 238

(fig), 15 226-232

høflighedsforskning $15210 \mathrm{f}$

høflighedsteori 15211

Høgh-Guldberg, Ove

bibeloversættelse 519

hørekorpora 119

Høy, Asta

sprogpolitik inden for lægevi-

denskab 22191

Høyem, S.

tysk som fremmedsprog 13336

Hoffmann, Lothar

fagsprog 3 76ff, 89 (def), 10104

vs terminologi 392

korporas repræsentativitet 1231 ,

234

kumulativ tekstanalyse 489

subsprogsteorien 10104

Hofstede, Geert

kultur 13347 (def)

-analyse og interkulturel

kommunikation 20152

Holbek, Bengt

ordsprog $3679 f$

Holberg, Ludvig

europæisk kultur 36183

Holck, Niels

kommatering 13326

tegnsætning 13323

Hollandsk-Dansk Dansk-Hollandsk

Ordbog (Paludan)

anmeldelse 18 246-249

Hollandsk-dansk ordbog (Gyld) 20

199
Holm, Lis

oversættelsesteori og -praksis $\mathbf{1 6}$

236-238

Holste, Alice L.

Russisk-dansk juridisk ordbog 24

190-196

homografi

pseudo- 12208

homonymer 2945

homonymi 2945 (def), 46 (fig)

Honey, Peter

Kolbs læringshjul 3064

Horst, J.A.M. van der informationsteknologi 2191

Hubin, $P$.

reklametekster $2152 \mathrm{f}$

Huddleston, Rodney

analytisk modus 1139

Humbley, John informatikterminologi $364 \mathrm{f}$

Husserl, Edmund

betydning 282

hvisketolkning 11149

hybriddannelser 359

hypertekster 30 88, 36158 (def)

kohærens i 36 157-178

kohæsion i 36 157-178

vs lineære 36 159, 161, 164, 169,

171,177

hypokoristika

i spansk $26121 \mathrm{f}$

hypotetisk rum 26 139, 30 134f, 140f

hypothetical space $\rightarrow$ hypotetisk rum

\section{I}

I-sprog 233 (def)

IAS $\rightarrow$ International Accounting

Standards

IATE 3096

identitet 27144 (def), $34163 \mathrm{f}$

idiomaticitet 3678

markering i ordbøger 25 175-180

idiomatik

vs fraseologi 25172 
idiomatisk distance $25192 \mathrm{f}$ idiomatisk hyperdistance 25 191-193

idiomatisk indhold 35140 idiomatisk indholdslag 35 136ff idiomatisk interferens 25187 idiomatiske arkaismer 25186 idiosynkratiske former $25188 \mathrm{f}$ kontrastive normer 25 187, 192 i moderne dansk-tysk leksikografi 25 171-199

se også bevingede ord; falsche Freunde; fraseologi; kollokationer; ordsprog; parømiologi; talemåder; vendinger idiomatisering 35137 idiomer 32210 (def), 35 99, 155, 171 (def), 36 77-89, 79 (def) ambiguitet 25175 begrebet 32 207-211

i Den Danske Idiomordbog leksikografisk udmøntning 32 212-219

teoretiske problemer 32 213-215 billedlighed 3678 danismer $25190 \mathrm{f}$ definitioner 32 207, 218f negative vs positive 32 209-211 den diakrone udvikling 35143 eksternt argument 35123 germanismer 25 186f vs kollokationer 35 111f, 171f 176-179

lemmatisering af 25 183-189 metaforiske 35155

på nettet 32 201-234 vs ordsprog 32 213f, 36 82-87 paradigmatisk funktion $35144 \mathrm{f}$ paradigmedannelse 35144 reproducerbarhed 3678 semantisk variation 35 119-132 somato- 25175 stabilitet $\mathbf{3 6} 78$ og reproducerbarhed 35 145-147 typiske træk 36 77-79 valens

intern og ekstern 32 222-225

semantisk

variation $35127 \mathrm{f}$

idiotkomma 13324

IFF Fagordbog dansk/engelskengelsk/dansk 2 56ff, 7 156, 1069 anmeldelse 1 251-255

IFRS $\rightarrow$ International Financial Reporting Standards illocutionary acts $\mathbf{3} 233,1939$ illokution 30138 image 27144 (def), 34 163f image space $\rightarrow$ afbildningsrum; fiktionsrum

IMAGE-IDEA-PAIR 35 214f

verber 35 216-219

indholdsform 17148 (def)

indholdsstruktur 17 154-158

indholdssubstans 17148 (def), 154-

158

indikativ

vs konjunktiv 1 32-34

spansk 20 278f, 29 269f

i tyske forretningsbreve 131

i vesttyske domsudskrifter 133

indirekte gengivelser 30 147f

indirekte tale

tysk 1 25-35

Indirektheitskontexte 30147

individualbegreber 3 100-104, 15188

indlærer

termen 3016

induktiv arbejdsmetode 18

inferenslove $191 \mathrm{f}$

argumentative $191 \mathrm{f}$

infinitiv

ledsætninger 321

substantiveret $29270 \mathrm{f}$

informanter 1 13-16

tests med $121 \mathrm{f}$

information(s) $13255 \mathrm{f}$

-cocktail 13 276-278

-forarbejdning kognitiv $\mathbf{3 0} 18 \mathrm{f}$ 
-formidling 13 255-257

-forvaltning $3077 \mathrm{f}$

-præsentation $3092 \mathrm{f}$

-registrering 30 90-92

-søgning 30 78-88

-struktur

på sætnings-/ytringsniveau 13

251-278

-teknologi $\rightarrow$ IT

-vurdering 30 88f

overload 36162

Ingo, Rune

terminologi og fagsprogsover-

sættelse 22191

inkongruens 14249

neutrumsprædikativ

dansk og svensk 14249

inputforarbejdning 3022

instigator 17 156-159, 156 (def)

Institutionsnavne dansk-engelsk

anmeldelse 29 263-268

intension 19 117, $20265 f$ (def)

intention

direktiv 15212

ekspressiv 15212

intentionsanalyse $\mathbf{1 5} 266$

interaktion 20153

underviser og studerende 30 31, 117-121

interfacesprog $\mathbf{3 0} 85$

International Accounting Standards

34280

International Financial Reporting

Standards $\mathbf{3 4} 280$

Internet

-tekster 36 157-178

begrebet 3082

og fagleksikografi 29 340ff

kvalitet 3089

ressourcer 30 93-97

opslagsværker $3095 \mathrm{f}$

portaler 3094

tekster 3094

i sprogundervisningen 30 75-99 vs webben 3082

se også web

interpersonelt rum 26139

interpretation 154 (def), 54f, 13

254 (def)

intersprog 30 16, 17 (def), 30

grundlæggende karakteristika 3017

omstrukturering 30 19f

og SLA 30 16-21

interviews 4 139-143

Intranet

og fagleksikografi $29340 \mathrm{ff}$

intraposition 1154

introspektion 1 10-12, 21, 157, 27202

irrealt rum 26 139, 30 135, 141f

islandsk

fraseologi

dansk-islandsk 35155

isotopi 36172 (def)

figurativ 151

hierarkisering $152 \mathrm{f}$

som kohæsionsskabende middel

$36172 \mathrm{f}$

semantisk 1 45-61

indholdsform vs indholdssub-

stans 147

kritik af begrebet 1 52-54, 59

semiologisk $151 \mathrm{f}$

tematisk 151

IT

-terminologi 3 60-69, 30 75-99

dansk

purisme i 5147

fransk 3 60-69

proveniensen af 365

metaforer i 23 173-200

og sprog 30 75-99

og sproglig læring 30 13-34

computermediets

differentieringspotentiale $\mathbf{3 0}$

13-34

i sprogundervisningen 30 7-11,

57-72, 75-99, 101-128

symposium om EDB 13 305-309 
italiensk

artikelbrug 20265

artikelsyntaks 20 264-269

vs dansk spørgsmål og svar 19 29-50 uoversættelige ord 15256

fraseologiske somatismer

i italiensk, fransk og dansk 35157

grammatik 6 175-179

tryk 15257

Itkonen, Esa

tekstundersøgelser 116

\section{J}

ja/nej-spørgsmål 19 39f

Jackendoff, Ray

sandhedsbetingelser 284

semantisk idealisme 2141

Jacobsen, Henrik Galberg

anmelderi 19 133-142

danske dobbeltformer 11 143-148

kommatering 13 319-326

surveys $27206 \mathrm{f}$

Jacobsen, Jane R.

eksempler i ordbøger 18164

Järborg, Jerker

opsplitning af leksemer 35131

Järvi, Quti

informatøruddannelsen på Vasa

Universitet 13305

Jagtsproget (ordbog) anmeldelse 20 247-254

Jakobsen, Lisbeth Falster Prazt 13358

Jakobson, Roman

sprogfunktioner 1202

Jansz, Litza

kultur 28186 (def)

japansk

fraseologi

dansk-japansk 35158

Jarvad, Pia

Konference om Leksikografi i

Norden 14 236-238 nye ord 16 238-241

Nye ord i dansk 1955-1998 26

173-175

sprogpolitik 31 136f

Jefferson, Gail

konversationsanalyse $20142 \mathrm{f}$

Jensen, Iben

kulturforståelse 36 227ff

Jensen, Jørgen Schmitt

italiensk grammatik 6 175-179

Jensen, Kjær

ordbogslayout 443

spansk grammatik 7 175-178

verbet caer's semantik 29273

Jensen, Sanne

informanter i ordbogsarbejde 27

207f

Jeppesen, Anne M.E.

udviklingsstudier og interkulturel

virksomhedsstrategi 13345

Jørgensen, Charlotte

retorik 14 245-248

Jørgensen, Keld G.

sproglig tekstanalyse 19 268-279

stilistik 18216226

Jørgensen, K.R.

europæisk kirke- og religionsret 36186

Jørgensen, Peter

indirekte gengivelser 30147

konjunktiv 126

tekst 30145

Jørgensen, Peter Stray

anmelderi 19 133-142

Johansen, Marianne

samtaleanalyse 13357

Johansen, Winni

international markedskommuni-

kation 20 245-247

Johnsen, Lars

tekstoptimeringsværktøjer 13305

Johnson, Mark

kritik af 23173

metaforer 18 229, 23 174-179,

196-199 
metaforforskningen 29 302-305

jokerord 364

Jón H. Jónsson

Nordisk leksikografisk ordbok 20 235-242

Jones, W. Glyn

Institutionsnavne dansk-engelsk 29 263-268

Jong, T. de

tværkulturel forhandling 2190

Jowitt's Dictionary of Enlish Law

$256 \mathrm{ff}$

Jürgensen, Peter

Dansk-tysk ordbog (Munk) 10

133-141

Juliá, Tomás Jiménez

funktionel syntaktisk analyse 5

137-142

Juridisk ordbog dansk-engelsk

(Pals Frandsen)

anmeldelse 18 208-216

Juridisk ordbog dansk-tysk (Gubba)

lemmatisering af ordforbindelser

18167

Juridisk ordbog dansk-tysk

(Henriksen)

lemmatisering af ordforbindelser $18168 \mathrm{f}$

Juridisk ordbog engelsk-dansk

(Pals Frandsen)

anmeldelse 14 225-235

lemmatisering af ordforbindelser 18169

Juridisk ordbog spansk-dansk

(Gad) 5 127-136, 7 109-114

Juridisk ordbog tysk-dansk (Gubba) lemmatisering af ordforbindelser

i 18167

Juridisk ordbog (von Eyben) $256 \mathrm{ff}$

juridisk sprog 5 123-126

teksttypologisk undersøgelse $\mathbf{2 0}$

84-104

juridiske ordbøger

danske 2 55-74

engelske 2 55-74 lemmata og eksempler i 18 157-172

Juul, Arne

Institutionsnavne dansk-engelsk

29 263-268

Juul Madsen, C.A.

Dansk-italiensk ordbog 15 254-261

Juul Madsen, H.

Dansk-italiensk ordbog 15 254-261

\section{$\mathbf{K}$}

K-kommando 1167

kædestrukturer, leksikalske $2196 \mathrm{f}$

Källström, Roger

kongruens i svensk $14248 f$

Kalkar, Chr. H.

bibeloversættelse 519

Kamp, Hans semantisk konstruktivisme 2142

Karker, Allan

bibeloversættelse 524

dansk i EF 13 310-318

dansk sproghistorie $14250 \mathrm{f}$

juridisk sprog 4130

Karlberg, Maria

retorik 23 239-241

Kastberg, Peter

teknisk oversættelse $29261 f$

kasus

-filter 1 172-174

-roller $172 \mathrm{ff}$

-teorien 1 71ff

semantiske $175 \mathrm{f}$

kataforer 21222 (def)

og forik $21221 \mathrm{f}$

og funktion 21219

og informationsstruktur $21220 \mathrm{f}$

og kontinuitet $21219 \mathrm{f}$

pronominelle 21 217-222

og typologisering $\mathbf{2 1} 218 \mathrm{f}$

kataforik 21 217-222

kataforisk relation 21217

katastrofeteorien

semantiske katastrofeskemaer 19

118-128 
100

sommerfugl $19119 f$

kategorier

Boolske upræcise $1136 f$

definition af $\mathbf{1} 135$

generelle sproglige $\mathbf{1} 137 \mathrm{f}$

styrende 1180 (def)

tomme 1 153-184

Katlev, Jan

fraseologi og etymologi 35154

Katz, Jerold J.

leksemanalyse $292 \mathrm{f}$

svag antirepræsentationalisme 2140

Kaufmann, Uwe

fagrelateret ordbogsartikel 1066

Genteknologisk ordbog 10 79-93,

11 123-129, 12 183f

Molekylcr Biologisk Leksikon 1080

kausalitet

i ESP 3 11-27

Kawashima, Atsuo

idiomer 3678

Kemisk Ordbog (L\&H) 10 77-79

kernesemer $1107 \mathrm{f}$

Kewley-Draskau, J.

fagsprogsoversættelse 15266

Khader, Naser

plagiat 34275

Kierkegaard, Søren

anmelderi 19139

kildeområde 23175

Kiparsky, Carol

faktuel præsupposition 2154

Kiparsky, Paul

faktuel præsupposition 2154

kippefænomenet 2937 (fig)

kirkeret

dansk 36186

europæisk 36186

Kjær, Anne Lise

europæisk retskultur $36181 \mathrm{ff}$

jurister og journalister $36186 f$

retlige aktører 36182

retskulturforskning 36187

Kjær, Iver

ordsprog $3679 f$
Kjørup, Søren

semiotik 30235

klassemer 1 49ff, 107-109, 295

(def), 14153

klassematisk basis $\mathbf{1}$ 108, 114

Kleines Valenzlexikon deutscher

Verben

introspektionens problem 112

Klimenok, Svetlana

oversættelse af drama 18206

Klitgård, Ida

oversættelse af Virginia Woolf 18

206

Kloepfer, Rolf

die primitiv-wörtliche Übersetz-

ung 28187

knækstrukturer 27 125-134

Knauer, Gabriele

indikativ vs konjunktiv i spansk

29270

Knoth, Tine W.

indirekte gengivelser 30147

knowledge-telling $14205 \mathrm{f}$

knowledge-transforming $\mathbf{1 4} 205 f$

knuder

begrænsede 1177

tomme $1154 \mathrm{ff}$

Knudsen, Anne

europæisk retskultur $36181 \mathrm{f}$

Knudsen, Christian

essens 28159

Kobbernagel, Jan

erhvervsret 21143

Koch, Christian

skrivepædagogik 22 172-175

Koch, Henning

europæisk retskultur $36181 \mathrm{ff}$

modstandsret 36184

retlige aktører 36182

retskultur 36188 (def)

Kock, Christian

retorik 14 245-248

kohærens 14 203-205, 20 22, 21

153-156, 26 137-148, 36 157, 160

(def) 
global vs lokal $36163 \mathrm{f}$

i hypertekster 36 157-178

tekstpragmatisk $1122 \mathrm{f}$

tekstsemantisk 1 124-131

tekstsyntaktisk $1123 \mathrm{f}$

tekstuel 1 46ff, 47 (def), 54, 60, 122-131

fag- 1 48, 14 259-266

kohæsion 1 123, 2 123f, 13 271f,

14 203-205, 20 22, 21 153-156, 36

157,162 (def)

global vs lokal $36163 \mathrm{f}$

i hypertekster 36 157-178

Kolb, David A.

læring 3062

læringsstil 3064

læringstyper 30 63f

kollokationer 32 216-218, 35104

(def), 106 (def), 108 (def), 111-113,

155,171 (def)

åbne 35177 (def)

begrebet

i korpuslingvistik 35 108-110

forskellige synsvinkler 35 113f

empirisk-statistisk beskrivelse

35113

leksikografisk beskrivelse 35

103-107, 114f

lingvistisk beskrivelse $35113 \mathrm{f}$

grammatiske 35107

halv-lukkede 35178

vs idiomer 35 111f, 171f, 176-179

kategoriens afgrænsning $35101 \mathrm{f}$

fraseologisk 35 97-116

leksikalske 35107

i leksikografisk praksis 35 110-113

lukkede 35177 (def), 180

som sprogligt problem $35102 \mathrm{f}$

termen 35 98f

kolon

-typologi 21 156-173

årsags- 21169 (def), 169f, 175

anførende 21157 (def), 157f, 174

dobbelt- 21172 (def), 172f

eksempel- 21167 (def), 167f emfatisk 21163 (def), 163f, 174

følge- 21170 (def), 170f, 175

i fransk 21 151-178

indrømmende 21160 (def), 160f,

175

journalistisk 21164 (def), 164f, 175

legitimerende 21169 (def), 169f,

175

modsætnings- 21161 (def), 161f,

175

præciserende 21158 (def), 158f,

$174 f$

resumerende 21171 (def), 171f, 175

retorisk spørgsmåls- 21159 (def),

159f, 175

skjult citat- 21162 (def), 162f, 175

statistik- 21168 (def), 168f, 174

temporalt 21166 (def), 166f, 174

uddybende 21165 (def), 165f, 174

komma

enheds- 13 319-326

fraserings- 13321

funktions- 13322

grammatisk 13 319-325

idiot- 13324

nyt 31161

pause- 13 319-325

kommatering 13 319-326

de danske kommaers jubilæum

13319

funktion og betydning i tysk 15287

historie i Danmark 13 319f

kommissiv direktiver 26 123, 128,

132

kommissiver 26123

kommunikation 2 213-216, 3 116,

224, 5 116, 14 238-244, 20153

afsender-modtager-relationen 3

239 (fig)

elementer $2938 \mathrm{f}$

fag- 10 103-108, 36193

inter- 36193

formler 3599

handlinger 3 238, 20143

interkulturel 3-219-244, 13 340- 
348, 14 196, 20 139-160

forskningstraditioner

etnometodologi-skolen $3220 \mathrm{f}$

konstruktivisme-skolen 3221

social action-skolen 221

høflighed i 3 227-230

vs intrakulturel 3223 (fig)

kompetence 315 (def), 4 88, 93,

$5115 f$

kulturelle barrierer 20148

Leechs model 3179 (fig)

markeds-

international 20 245-247

meta- 5116

retsregler 5 113-121

situationen 3 237-241, 4 105-107

synonymitet $\mathbf{3} 182$

virksomheds- 27 139-166

autoritet 27148

distance 27148

og systemisk funktionel lingvis-

tik 34 143-166

virksomhedspræsentationer 27

139-166

den horisontale relation 27

149-159

den vertikale relation 27 159165

se også anmodninger; høflighed; konversationsanalyse; konversationsmaksimer; sproghandlinger; sprogkompetens

kommunikationsanalyse

model 34148 (fig)

og SFL 34 148-160

kommunikationsplanlægning model, den dynamiske 34 160

164, 160 (fig)

og SFL 34 160-163

kommunikationssfære 1201 (def)

kommutationsprøven 4 93f

komparativ

koordinerende konstruktioner 17

258

korrigerende konstruktioner 17260 pseudo- 17257 (def)

spansk 17 257-260

relative komparativer $\mathbf{1 7} 256$

spansk

sproglige sammenligninger $\mathbf{1 7}$ $255 \mathrm{f}$

strukturer 17 255-260

strukturer 17256 (def)

kompetencenormer 5 117, 120

komplementaritet 2197

komponentanalyse 2 90-94

komposita

fagsproglige 8 29-42

dansk 8 32-35

engelsk 8 32-35

ikke-leksikaliserede 830

klassifikation og oversættelse af

$835 f$

leksikaliserede $829 \mathrm{f}$

komposition 3 55, 8 29f, 18223

(def)

de- 830

koncernfagleksikografi 29 339-347

intranetbaseret 29 339-347

holistisk og socialkonstruktivistisk model 29343 (fig)

konfiks 358

konfiksation $358 \mathrm{f}$

kongruens 3180 (def), 180f

svensk $14248 \mathrm{f}$

konjektur 527

konjunktiv

dansk 17146

ikke-obligatorisk 130

vs indikativ $132-34$

obligatorisk 133

spansk $20278 f$

tysk 1 26-35

konkordans

-programmer 3097

bogstavpar- 137

linie- 138

morfem- 138

konneksionsanvisninger 21220

konneksitet $2022 \mathrm{f}$ 
konnektiver

som kohæsionsskabende middel

36178

konnektorer 3 21, 21 34-36

ensrettere 2135

kolon som konnektor

i fransk 21 151-178

konnektion og argumentation 21

$155 \mathrm{f}$

modsatrettere 2135

pragmatiske 30241

konstitutivt rum 26 139, 30 135f, 145

konsultationsgrammatik 6 175f

kontekstlingvistik 1122

kontekstsemer 1109

kontinuativa 29 62-65

kontinuitet 21219

kontrast

leksikalsk 2197

semantisk 2197

kontrastfokus $13267 \mathrm{f}$

kontrol 1930 (def)

konversationsanalyse 4 139-143, 13

356-358, 20 139-160

antropologisk 20145

etnografisk 20145

etnometodologisk 20 139-160

grundlæggende antagelser 20

141-145

metodologiske forhold 20 141-145

vs kulturanalyse og antropologi

20 156-159

metalingvistiske rammekonstruk-

tioner 20149

preface 20149

samtaleregulerende mekanismer

14208

samtalesituationer 14196

konversationsmaksimer 4 92f, 14

222, 15 226, 27165

kvalitetsmaksimet 4 92, 15 226,

27165

kvantitetsmaksimet 4 92f, 15 226,

27165

mådesmaksimet 15226 modalmaksimet 493

relationsmaksimet 493

relevansmaksimet 15 226, 27165

koordination $321 \mathrm{f}$

Kopczynski, Andrzej

simultantolkning 3180

Korlén, Gustav

tysk fonetik 15273

korpora $\rightarrow$ hørekorpora; læsekor-

pora; tekstkorpora

korpuslingvistik 1 229, 29269

kollokationsbegrebet i 35 108-110

korrelativer 17258

korrelatnomen 15283

korrespondens 3180 (def), $180 \mathrm{f}$

Korsgaard Sørensen, E.

\section{NBL 30125}

online 30104

kortformer 14280 (def)

korttidshukommelse 3018

Korzen, Hanne

semantiske roller $19116 \mathrm{ff}$

Korzen, Iørn

artikelsyntaks i italiensk 20 264-269

Kožina, M.N.

funktionalstile $1201 \mathrm{ff}$

Kragh, Simon Ulrik

interkulturel virksomhedsledelse

$13343 f$

Kramer, Undine

leksikologi vs leksikografi 29

21-30

kreolisering, retlig 36186

Krogh-Hansen, Niels

oversættelse $15262 \mathrm{ff}$

fagsprogs- $15266 \mathrm{f}$

teknisk sprog $\mathbf{2 8} 180 \mathrm{ff}$

Kromann, Hans-Peder

aktiv-passiv-teori 26156

erhvervssprog 13 305, 21149

forskning 3 281-283, 21140

Kronning, Hans

polyfonikonfiguration 2128

veridiktion og monstration 13257 


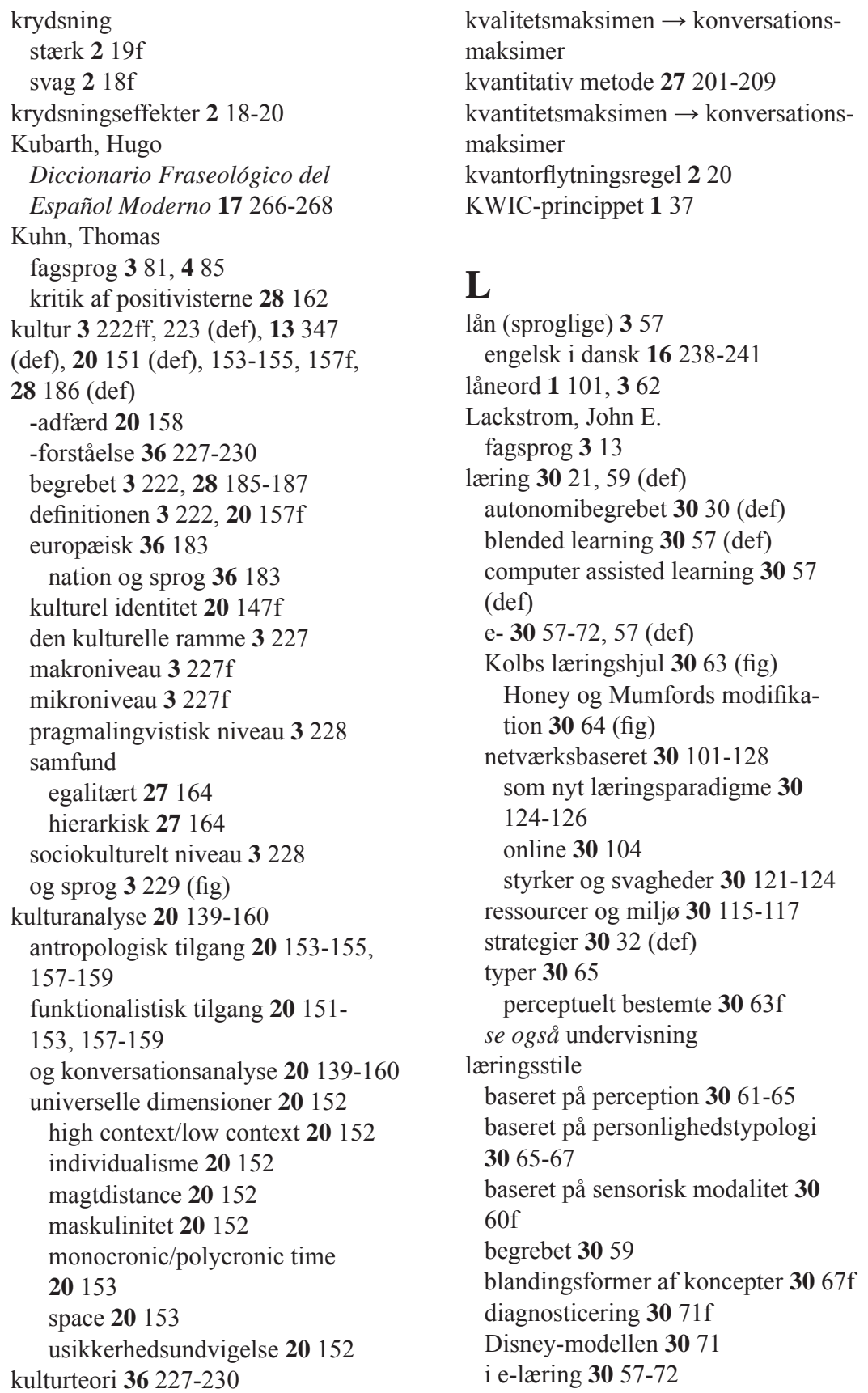


Felder/Silverman-modellen $\mathbf{3 0} 68$ Freuds model 3071

den naturlige udvælgelse 30 68-71 områder 3068

læsekorpora 119

læsning

beskrivende 156

default- 13254

producerende 157

tabulær vs linær 153

teori om 1 48f, 53

Lago, Ángel F.

spansk handelssprog 23 242-244

Lakoff, George

høflighed 15211

kritik af 23173

metaforer 18 229, 23 174-179,

196-199

forskningen 29 302-305

semantisk idealisme 2141

Lalande, A

definition af struktur 287

LAMBDA 5 153ff

Landbrug/levnedsmiddel Ordbog

(L\&H) 10 73-76

vs Dairy Vocabulary 1076

vs Dictionary of Dairy

Terminology 1076

Lang, Ewald

encyklopædiske angivelser i ordbøger $2926 \mathrm{f}$

leksikologi vs leksikografi 2923

Langacker, R.

semantisk idealisme 2141

Lange, Henrik

Dansk-tysk ordbog (Munk) 10

133-141

Langkilde, Charlotte

Teknisk Ordbog (L\&H) 9 197-204

langtidshukommelse 3018

Larsen, Erik V.

dansk grammatik for svenskere

$26168 f$
Larsen, Henry V.

Dansk-tysk ordbog (Munk) 10

133-141

Larsen, Peter Harms

fagsprog 1 245-250, 15198

kommunikation 2 213-216

Larsen, Vibeke Vrang $\rightarrow$ Vrang,

Vibeke

Last Resort 27114

Laurén, Christer fagsprog 3 76ff, $14 \mathrm{ff}$

teknolekt 15291 (def)

Lauridsen, Carsten

fordelingsstruktur 21132

henvisningsstruktur 21 133f

Lauridsen, Karen M.

anmelderi/Dansk-engelsk ordbog

(V/B) 19136

DIALANG 3010

DK87 1234

et juridisk tekstkorpus 1210

Lauridsen, Ole

anmelderi/Gads Tysk Large 19

135,140

DK87 1234

hypotetiske betingelseskom-

plekser 30 141, 143

IT på videregående uddannelser

3010

tysk grammatik 16 252-255

Lauritsen, M.B.

sprogpolitik 31 167-170

Laursen, Anna-Lise

anmelderi/Orlando Galindos

fagordbøger 19140

anmelderiets nyttesløshed? 19174

IFF Fagordbog 1069

Lavacchi, Leonardo

sætningskløvning i spansk 29272

Lawrenz, B.

frie appositioner $15287 \mathrm{f}$

layout

i ordbøger 4 31-46

learner

termen $\mathbf{3 0} 16$ 
106

learning $\rightarrow$ læring

lectio difficilior $\mathbf{5} 26$

Lederer, Marianne

simultantolkning 3 184ff

Ledin, Per

brugstekstanalyse 20 255-259

ledsætninger

adverbielle 320

infinitte 321

Leech, Geoffrey

encyklopædisk vs sproglig viden

$285 f$

den kommunikative situation 3

179 (fig)

Leirbukt, Oddleif

fremmedsprogstilegnelse 13 332340

leksemanalyse 2 83ff

semasiologisk fremgangsmåde 2

91ff

se også betydning; leksikon

(sprogets); semanalyse

leksemer 1 106, 14266 (def)

kerne- og underbetydning $35122 \mathrm{f}$

leksika $\rightarrow$ ordbøger

leksikaliserethed 3678

leksikalsk anisomorfisme 286

leksikalsk kontrast 2197

leksikalske enheder 2 194, 351 (def)

leksikalske kædestrukturer 2 196f

leksikalske strukturer 2 86-90

leksikalske subsystemer $2102 \mathrm{f}$

leksikografi 13 293, 20 182-184

aktiv-passiv-teori 26156

dansk-tysk

idiomatik 25 171-199

data (leksikografiske) 21 132f

til hjælp ved korrektur

oversættelser 33 137-143

tekster på modersmålet 33

126-129

til hjælp ved oversættelse $33135 f$

placering og indbyrdes relationer

$21132 \mathrm{f}$

nulrelation $21133 \mathrm{f}$ primære 33 124-126

til hjælp ved retning

tekster på modersmålet 33 129f

sekundære 33 124-126

til hjælp ved tekstproduktion

på modersmålet 33 124-126

data- $\mathbf{3 5} 115$

datakonvergens 29346

demokrati 29347

funktioner 21 122-124, 123 (def)

direkte vs indirekte 21124

kommunikationsorienterede vs

vidensorienterede 21124

korrektur 33 117-147

delfaser 33122 (fig)

kommunikationsmodel 33

120 (fig)

original tekst og oversættelse

33134 (fig)

vs retning 33123,130

vs tekstproduktion 33132

udkast og tekst 33121 (fig)

oversættelse

til og fra modersmålet 33 133f

retning 33 117-147

delfaser 33123 (fig)

vs korrektur 33 123, 130

vs tekstproduktion 33132

tekstproduktion

på fremmedsprog $33132 \mathrm{f}$

vs korrektur 33132

på modersmålet 33 118-124

vs retning 33132

tekstrelaterede vs ikke-tekstre-

laterede 21124

funktionslæren 29 331, 33118

grænsefladetilpasning 29345

historisk-kognitiv 18236 (def)

idiomatik

dansk-tysk 25 171-199

kognitiv 18 228-237, 235 (def)

kollokationer

i leksikografisk praksis 35110 -

113 
metaleksikografiske beskrivelser og definitioner 35 103-107

2. Konference om Leksikografi i Norden 14 236-238

leksikografisk helhedsmodel 21 132 (fig)

vs leksikologi 29 21-30

lingvistikkens indflydelse $2921 \mathrm{f}$

praktisk vs teoretisk 20182

strukturer

Datendistributions- 21 132, 135

fordelings- 21135 (def), 135 (fig)

begrebet 21132

$i$ et brugerorienteret perspek-

tiv 21 121-136

vs henvisningsstruktur 21 133f

makro- 157 (def)

kompleks 257 (def)

simpel 257 (def)

mega- 21132

mikro- 263 (def)

terminologisk 13306

termen $\mathbf{1 3} 306$

unifikation $29332 \mathrm{f}$

unifikationsprincippet 29332

videndelingssystemer

intranetbaserede 29 339-347

se også fagleksikografi; fagordbøger; ordbøger

leksikogrammatik 34 146, 150, 153

leksikologi

vs leksikografi 29 21-30

leksikon (sprogets) 2 87, 102 (fig)

leksikotainment $\rightarrow$ lexicotainment

Lelubres, Xavier

termdannelse

arabisk vs græsk-latinsk 12163

lemma 2 58, 18165

-angivelse 264 (def)

-bestand 258 (def)

-hul 29203 (def)

-lig 29203 (def)

-opstilling 2 60-63

nichestrukturel 261 (def)

redestrukturel 261 (def), 61f se også sorteringsprincipper

basis- 264 (def)

ledeelementer

lemmaeksterne 265

lemmainterne 265

missing lemma bashing 32202

strukturelt tilhørsforhold 263

sub- 265 (def)

León, Fernando S.

opbygning af CREA og CORDE

$29275 f$

Lettisk-dansk/dansk-lettisk grundordbog

anmeldelse 16 225-228

Levelt, W.J.L.

intuitionen 111

Levinson, $\mathrm{S}$.

høflighedsteori 15211

lexicotainment 32205

Liebert, Wolf-Andreas

metafordomæner i tysk hver-

dagssprog 18 228-237

Liebing, Christian

Tysk-dansk ordbog (Gyld) 11155

Liep, John

kultur 20151

Lightbown, P.M.

intersprogets omstrukturering $\mathbf{3 0} 20$

Liljestrand, Birger

stilistik 16 245-252

Limas-Korpus 1 18, $231 \mathrm{f}$

Lindberg, J. Chr.

bibeloversættelse 519

Lindegaard, Annette skønlitterær oversættelse $18207 \mathrm{f}$

Lindegård Hjorth, Poul anmelderi 19140 grammatisk komma 13320

Lindemann, Beate fremmedsprogstilegnelse 13 332340

modalverberne i $13338 \mathrm{f}$

Lindgaard, Jens

tysk fonetik 15273 
Lindström, Fredrik sproglig folkeoplysning $27213 \mathrm{f}$ linguistic absurdity $285 \mathrm{f}$ lingvistik $15245 \mathrm{ff}$ almensproglig vs fagsproglig realiaforskning 1 192-194

babylonisering af $\mathbf{1 7} 104$

data- 5 153-156, 35115 som erhvervssproglig forskning -sgren 5 153-156

deskriptiv 17 103-112

vs præskriptiv 21 101-107

empiriske metoder i 1 7-22, 27

201-209

folke- 36 183, 195

indflydelse på leksikografien $2921 \mathrm{f}$

kognitiv 18 228-237

og metaforer 18 229-235

se også begivenhedsmodel;

billardkuglemodel; scenemodel

kontekst- 1122

korpus- 1 229, 29269

kollokationsbegrebet i 35 108-110

Linguistik des Sinns 15292

lingvistiske undersøgelser

repræsentativitet 27 201-209

brugen af surveys i 27 201-209

øko- 14 219-224, 220 (def)

vs strukturalisme 14221

præskriptiv

vs deskriptiv 21 101-107

og samfundsforskning 4 101-122

systemisk funktionel 24 161-178

i Danmark 24 167-169

introduktion til 24 163-166

og kommunikationsanalyse 34

148-160

og kommunikationsplanlægning

34 160-163

og organisationskulturanalyse

34 153-155

og tekstproduktion 34 155-160

og virksomhedskommunikation

34 143-166 tekst- 1 85-95, 15 292, $18222 \mathrm{f}$

inferentielle love 188

retningslinjer

globale 30130 (def), 130f

lokale 30130 (def)

sammenhængslove 189

sammenkædningslove 188

teoretisk 17 103-112

transfrastisk 15292

og virksomhedskommunikation

34 143-166

se også deskription; præskription

lingvistpoesi 112

liniekonkordans 138

LOB-Corpus 1231

locus 19 115-129, 117 (def)

Löbel, E.

attributive appositioner $\mathbf{1 5} 287 \mathrm{f}$

Løgstrup, K.E.

sproget 27205

Løngreen, Hanne

interkulturel kommunikation $\mathbf{1 3}$

340-348

interkulturel virksomhedsstrategi

$13345 f$

lørner 3040 (def)

termen $\mathbf{3 0} 16$

logik

modal 1 146-150, 5 154-156

modallogiske operatorer 1 140ff, $1147 \mathrm{ff}$ (fig)

tids- $5155 \mathrm{f}$

logisk form 1158

logisk positivisme 3 88, 28 160f

lokativ 17157

dobbelt 19126

lokativisk rum 26139

lokutør 2068

ansvarsrelation 2071

ikke- 2071

enighedsrelation 2071

vs synspunkt 2068

Lombard, F.J.

lingvistik vs leksikografi 2922 
Lomborg, Bjørn

videnskabelig uredelighed $34265 \mathrm{ff}$

Lomheim, Sylfest

oversættelsesteori 3 317-319

Longman Citation Corpus 3314

Longman Dictionary of Contemporary English

anmeldelse 3 311-315

López, Cecilia R.

spansk handelssprog 23 242-244

Lorentzen, Henrik

Gyldendals, Politikens og Dansk

Sprognævns retskrivningsordbøger $29200 \mathrm{ff}$

LSP

termen

vs fagsprog 15183

se også fagsprog

Luhmann, Niklas

autopoiesis $\mathbf{2 8} 165$

systemteori 28 165-167

Lund, Anne K.

organisationers troværdighed 34163

Lund, Jørn

fremmedord i dansk $15261 \mathrm{f}$

stilistisk detektivarbejde 17261

Lundquist, Lita

kommunikationsproblemer og

retskultur 36184

oversættelse 21 188-194

Lurquin, Georges

informatikterminologi 3 61-63

Luther, Martin

bibeloversættelse $524 \mathrm{f}$

Lutherbibelen $517 \mathrm{f}$

lydhørhed 14171

Lyons, John

entiteter 2146

I-sproget 233

naivt-realistisk ontologi 2145

ords betydning 14150

paradigmatiske betydningsrela-

tioner $289 f$

\section{M}

målområde 23175

McIlvenny, Paul

kulturel identitet 20147

McLaughlin, Barry

SLA 3019

McLeod, Beverly

SLA 3019

Madagassisch-Deutsches Wörter-

buch / Rakibolana Malagasy-Alema layout 4 45f

Madsen, Bodil N.

datalingvistik på HHK 13305

Madsen, Dorte

oversættelse 15267

Madsen, Helle L.

diskurs 13359

Madsen, K.E.

ordbogslayout 443

Maegaard, Bente

et dansk korpus $1232 \mathrm{ff}$

Mafera, Giovanni

Dansk-italiensk ordbog 15 254-261

majonæse-krigen 12196

makrostruktur 26 143-147

makrostruktur (leksikografisk) 157

(def)

kompleks 257 (def)

simpel 257 (def)

Malmberg, Bertil

tysk fonetik 15273

Mandelbaum, Jenny

kulturanalyse 20147

Manley, James

eksempler i ordbøger 18164

Marcellesi, Christiane

informatikterminologi 361

Marillier, J.-F.

nominalgrupper $15281 \mathrm{ff}$

prænominal genitiv 15283

markering $1933 \mathrm{f}$

marking $14215 \mathrm{f}$

Marlangeóns, S.B.K. de 
adverbiers modificering af substantiver 29296

Marshall, G.R.

efterstillede ubøjede adjektiver 15 $283 \mathrm{f}$

Martin, J.R.

systemisk funktionel lingvistik 24 161-178

Martinet, Hanne

oversættelse 3318

Marton, W.

psykolingvistik og kontrastiv analyse $13337 \mathrm{f}$

massoreterne 5 28-30

ME-II 30 106ff

medicinsk engelsk 30 101-128

Medicinsk ordbog. Dansk-engelsk/

engelsk-dansk 20 195-198

anmeldelse 14 267-271

medicinske ordbøger 20 195-198

dansk-engelsk $1239-244$

mediopassiv $179 \mathrm{f}$

megastruktur (leksikografisk) 21132

mekaniske drills 3025

meningskontinuitet 36160

mentale rum 17 151, 26 137-148,

30 133-156, 240f

epistemisk værdi 30134 (def)

evidentiel værdi 30134 (def)

typer 30 134-136

se også afbildningsrum; anskuel-

sesrum; basisrum; domæne-rum;

eventuelt rum; generisk rum; hypotetisk rum; interpersonelt rum; irrealt rum; konstitutivt rum; lokativisk rum; præsuppositionsrum; realitetsrum; temporalt rum

Merk, V.

tværkulturel forhandling 2190

meronomi 2196

metaforer 29 301-311

felter $\mathbf{1 8} 231$

funktion og status 23200

Golfkrigsmetaforikken 23198 integrerede 23 189-192, 192

(fig), 197, 199

i IT-sprog 23 173-200

kildeområde 23175

og kognitiv lingvistik 18 229-235

Lakoff og Johnson 23 196-199

leksikaliserede 23199

leksikogrammatiske 34150

målområde 23175

metafordomæner

i tysk hverdagssprog 18 228-237

metaforiske begreber 23175 -

178, 197

metaforiske rum 23 180, 191f

integrerede 23200

motorvejs- og rejsemetaforik 23

181-189, 193-196

ordbog over $29306 f$

potentielle 23 182f, 193, 196, 199

og sproglige erfaringer 23196

stærke 1 112-114

svage 1 114-115

metaforforskning

empirisk konstruktivisme 29 306-

311

den kognitive tradition 29 302-306

scenarier $29301 \mathrm{ff}$

metaforisering 1 112-117

metafraseografi 32202

metakommunikation 5116

metaordbøger $\mathbf{3 0} 96$

metasøgemaskiner $\mathbf{3 0} 81$

metonymi 1 115-117

mexikansk

mexikanske og danske forhand-

linger

turn-taking i taleenheder 20149

Mieder, Wolfgang

ordsprog 3680,87

Mighetto, David

substantiveret infinitiv $29270 \mathrm{f}$

Mikkelsen, Hans Kristian

fagsprogsforskning 1195

Mikkelsen, Kristian

passivforskningen 170 
mikropropositioner 26 144-147

mikrostruktur 26 143-145

mikrostruktur (leksikografisk) 263

(def)

Miller, George

simultantolkning 3186

modal logik 1 146-150, 5 154-156

modallogiske operatorer 1 140ff,

1147 ff (fig)

modalitet 1138 (def), 140-150, 141

(def), 2 125, 19 38-43, 38 (def), 20

108 (fig), $2154 \mathrm{f}$

dansk vs tysk 135

epistemisk vs ikke-epistemisk 1

140-145

matrix for subkategorisering 1

147 ff (fig)

modale konstruktioner 17258

og modus 1 138f

mulige verdener $\mathbf{1} 145 \mathrm{f}$

semantisk definition af 1 140f

se også modus

modalmaksimen $\rightarrow$ konversations-

maksimer

modalverber 1140

i moderne engelsk og dansk 1

133-150

modifikatorer 21 29-32

afrealiserende $2129 \mathrm{f}$

realiserende 2129

modsatrettere 2135

modstandsret 36184

modularitet 36158

moduler 36 158ff

modus 1139 (def)

-brug

i tysk indirekte tale 1 25-35

i tyske domme $132-34$

analytisk $\mathbf{1}$ 139f

se også modalitet

modus-res teori 12162

Møller, Bernt

Dansk-fransk teknisk ordbog 7 115f

information management 3010 selektor og bruger (ordbøger) 21

129

teknisk sprog 1071

Møller, Kim

interkulturel virksomhedsledelse

13342

Møllmann, Anne

Dansk-fransk marketing ordbog

8 111-126

Moerman, Michael

konversationsanalyse 20 145-147

kulturanalyse 20140

Mogensen, Jan spansk grammatik 29 278-284

Mogensen, Jens E.

oversættelse 15269

tysk fonetik 15 272-281

Molbech, Christian sprogbrug/sprogrigtighed $21103 \mathrm{f}$

Molekylcer Biologisk Leksikon 10

80,82

monosemiering 29 48-51

monstration $13256 f$

Montague, Richard

semantisk realisme 2141

morfemer 1 106, 351 (def), 51f

definition 138

frakto- 359

morfemkonkordans 138

morfer

definition 138

morfologi

Thoms morfologiske arketyper 19 $118 \mathrm{f}$

Morgan, Gareth

organisationsbeskrivelse 34154

Morris, J.M.

kommunikation 2190

Mortensen, Ditte H.

registeropskrift 34 157-159

Moser, Barbara

simultantolkning 3 183f

motorvejsmetaforen 23 181, 193-196

Mourier, Lise 
Regnskabsordbogen danskengelsk 34 279-283

Mral, Brigitte retorik 23 239-241

Mugdan, Joachim bilingvale ordbøger 26158

korporas repræsentativitet 1231

mulighedsrum (=eventuelt rum) 26

139, 30 135, $143 \mathrm{f}$

multispektion 1 10, 13-16

Mumford, Alan

Kolbs læringshjul 3064

Munck, Lena

dansk teknisk sprogbrug 15 267f

Myking, Johan

begreb/genstand og tegn 22191

terminologi 22 189-192

\section{$\mathbf{N}$}

Naer, V.L.

funktionalstilistik $1202 \mathrm{ff}$

Näslund, Harry

referens og kohærens i fagtekster 14 259-266

Nakos, Dorothy

informatikterminologi $365 f$

nationaløkonomi

vs erhvervsøkonomi 21142

$\mathrm{NBL}=$ netværksbaseret læring $\rightarrow$

læring

NDO $\rightarrow$ Politikens Nudansk

Ordbog

neologi 353

engelsk i dansk 16 238-241

neologismer 1 98-101, 16 238-241

dannelse af 1 101-105

formelle $199 \mathrm{f}$

grafiske 362

grammatiske 3 57, 62

indholdselementer i 1105

semantiske 1 97-118, 3 57, 61f

typer 1 99-101

NET $\rightarrow$ Den Danske Netordbog

neutrumsprædikativ inkongruent

dansk og svensk 14249

Newton, Harry

Newton's Telecommunications

Dictionary 25 203-214

Newton's Telecommunications

Dictionary

anmeldelse 25 203-214

nexustematisering 334

nicheartikler 261 (def), 61f, 7149

implicit nichestruktur 261

se også lemmaopstilling; rede-

artikler; sorteringsprincipper

Nielsen, Anne E.

international markedskommuni-

kation 20 245-247

Nielsen, Sandro

Engelsk-dansk basisordbog 18170

IFF Fagordbog 1069

ordbogslayout 442

Regnskabsordbogen dansk-

engelsk 34 279-283

retskultur 36 191ff

Nielsen, Tinna

Russisk-dansk juridisk ordbog 24

190-196

Nissen, Gunnar

populær etymologi 7 179-181

niveau de la manifestation 1107

niveau immanent 1106

Nølke, Henning

semantiske roller $19116 \mathrm{ff}$

nominaldefinitioner 3 113, 28158

vs realdefinitioner $\mathbf{2 8} 158$

nominaler 21 39-65

nominale strukturer 321

nominale udtryk 492

se også substantiver

nominalgrupper $\rightarrow$ nominalsyntagmer

nominalisering 21 39-65

argumentstruktur 21 51-53

postmodifikation 2152

præmodifikation 2152

specifikation 21 51f

i moderne fransk 13 359-364 
morfologisk 1263

nominalnegationer

kein $15285 f$

nominalsyntagmer 17 239-243, 20

265-268

spansk

intern struktur 29294

referenceforhold 30 237-244

syntaks og semantik 15 281-289

tilføjelser til 15285

tysk 15 281-289

assymetri 15282

i ytringsenheder uden verbal 15288

se også substantivsyntagmer

nominaltemaer 3 35-37

fysisk manifestation 3 35-37

non-kompositionalitet 32209

Nordisk leksikografisk ordbok anmeldelse 20 235-242

fællesskandinavisk enhedsstræv

$21100 \mathrm{f}$

ordforbindelser og kollokationer 35 104f

Nordskriv-projektet 14 192, 203-205

normproblematikken 21 95-116

se også deskription; præskription; proskription; sprogrigtighed; usus imperans; usus imperium; usus tyrannus

Norrick, Neal R.

ordsprog $\mathbf{3 6} 80$

notional grammar 3 11-27

notions 3 13, 15-18, 15 (def), 22, 27

se også rhetorical techniques NP

-flytning 1 154ff, 2 9-16

klassifikation 1 175f

spansk

intern struktur 29291

subjekt-

-løftning 2 12-14

tom 1 153-184, 2 9-33

parasitisk $226 \mathrm{f}$

Nudansk Ordbog $\rightarrow$ Politikens Nudansk Ordbog
Nunan, David

autonomibegrebet 3030 (def)

læringsmæssige formål 3033

sprogundervisning 3019

Nuopponen, Anita

begreb og objekt 22191

informatøruddannelsen på Vasa

Universitet 13305

Nydanske Studier 13356

Nye ord 1955-1998

anmeldelse 26 173-175

Nye ord i dansk 1955-1975 26173

nyhedstekstning 13 235-249

Nyrup Rasmussen, Poul

plagiat 34275

NyS $\rightarrow$ Nydanske Studier

$\mathbf{O}$

objekt

direkte vs indirekte 29271

dobbeltrepræsentation

på spansk 29275

occitansk

old-

grammatikskrivning 19 69-74

økolingvistik 14 219-224, 220 (def)

vs strukturalisme $\mathbf{1 4} 221$

Örn Bjarnason

medicinsk terminologiarbejde 13 305

Ørsted, Jeanette

oversættelseserhvervet 15270

oldfransk

grammatikskrivning 19 69-74

oldoccitansk

grammatikskrivning 19 69-74

oldrussisk

benævnelsesstrategier 35219

betydninger 35 221-229

betydningspotentiale $35219 \mathrm{f}$

leksikaliseringsmønstre 35 221-229

vs moderne russisk 35 230-236

benævnelsesstrategier $35235 \mathrm{f}$

verber 
genus $35219 \mathrm{f}$

det verbale leksikon 35 219-229

Olivares, Victoria

ordbogslayout 443

Olwig, Karen F.

kultur 20151

Omvendt fremmedordbog

anmeldelse 10 143-154

OneLook Dictionary 3096

onomasiologi

vs semasiologi 2100

opacitet 14280

operatorer 1 90, 21 32-34

argumentative 190

modallogiske 1 140ff, 1 147ff (fig)

ord 9143 (def)

-længde

i dansk 9 149f

homonyme

vs homonyme fraser 35168

joker- 364

ord-for-ord-metoden 260 (def), 60f

se også sorteringsprincipper

ordbøger

ækvivalens 2 69-74, 69 (def)

-angivelse 269 (def)

-ansættelse af idiomer 25 189-193

falsche Freunde 25 189f

pseudoækvivalens 25189

-grad 270

betydningsrestriktioner $270 \mathrm{f}$

nul- 270

afskrift i 2143

aktiv-passiv-teorien 26156

aktive 272 (def), $72 \mathrm{f}$

al- 268 (def), 13292 (def)

betydningsforklaringer $\rightarrow$ defini-

tioner

branche- 16 267-274, 269 (def)

definitioner i 16272

fagsystematik i $16271 \mathrm{f}$

flerordsforbindelser i $16272 \mathrm{f}$

grammatiske oplysninger i 16273

illustrationer i 16272

lemmaselektion i 16 270f brugerbehov

objektive 21125

primære 21 125f, 127f

sekundære 21 125f, $128 \mathrm{f}$

subjektive 21125

brugeren 21 124-129

vs selektoren 21129

brugerforudsætninger

faglige 21124

leksikografiske 21125

sproglige 21124

brugervejledning 21 128f, 25

173-175

vs leksikografisk indledning 21 128

byggedele 21130 (fig)

$i$ et brugerorienteret perspektiv

21 121-136

brugsrelaterede 21129

hybride 21 134f

ikke-integrerede 21128

integrerede 21128

eksempler 18 161-164

funktion $18163 \mathrm{f}$

hale- 10135

typer 18164

eksplikationssprog 273 (def)

ekstensive 260

ekstra-leksikografiske oplysninger

i 21129

vs encyklopædier 14237

encyklopædiske 8 111, 13292 (def)

encyklopædiske angivelser i 29

26-29

etsprogede/monolingvale 256 (def)

flersprogede/multilingvale 256

(def)

form og indhold 21126 (fig), 126f

indre vs ydre form 21127

formål 21 122-124, 123 (def)

forord i 21129

fremmed-

omvending af 10144

omvendte

tysk og dansk 10154 
funktioner 21 122-124, 123 (def)

direkte vs indirekte 21124

kommunikationsorienterede vs vidensorienterede 21124

korrektur 33 117-147

delfaser 33122 (fig)

kommunikationsmodel 33

120 (fig)

original tekst og oversættelse

33134 (fig)

vs retning 33123,130

vs tekstproduktion 33132

udkast og tekst 33121 (fig)

oversættelse

til og fra modersmålet 33 133f

retning 33 117-147

delfaser 33123 (fig)

vs korrektur 33 123, 130

vs tekstproduktion 33132

tekstproduktion

på fremmedsprog 33 132f

vs korrektur 33132

på modersmålet 33 118-124

vs retning 33132

tekstrelaterede vs ikke-tekstre-

laterede 21124

genbrug af ordbogsdata 14238

genre- $29331 \mathrm{f}$

grammatik i 33190

Gyldendals røde 26153

tysk 127

af medarbejdere på HHÅ eller i

kooperation med disse 20 184-186 idiomatik i $25171 \mathrm{ff}$

ækvivalensansættelse 25 189-193

alfabetisering af polyleksikal-

ske syntagmer 25 173-175

idiomatiske arkaismer 25186

lemmatisering 25 183-189

markering af idiomaticitet 25

175-180

opstilling 25 174, 180-183

ordsprogsdominans 25188

juridiske

dansk 2 55-74 engelsk 2 55-74

lemmata og eksempler i 18

157-172

layout 4 31-46

maksimerende 259 (def), 59f

medicinske 20 195-198

dansk-engelsk 1 239-244

meta- 3096

minimerende 259 (def), $59 \mathrm{f}$

omvendte fremmed-

tysk og dansk 10154

ordbogskriminalitet 1 252, 7155

ordforbindelser i 18 157f

oversættelses-

ækvivalenter i 2 217-220

eksempler

unificerende 29 327-336

grundlag og løsninger 29 327-336

oversigtsartikler 21132

passive 273 (def)

politiske og ideologiske hold-

ninger i $13366 f$

produktions-

variantangivelser i 21 95-116

retskrivnings- 29 197-215

sag- 13292 (def)

selektion

ydre 25193

selektive 260

selektoren

vs brugeren 21129

semantiske angivelser 29 26-29

spansk-dansk

almensproglige 5 127-130

special- 10 73-93

sprog- 13292 (def)

strukturer

Datendistributions- 21 132, 135

fordelings- 21135 (def), 135 (fig)

begrebet 21132

$i$ et brugerorienteret perspek-

tiv 21 121-136

vs henvisningsstruktur $21133 \mathrm{f}$

makro- 157 (def)

kompleks 257 (def) 


\author{
simpel 257 (def) \\ mega- 21132 \\ mikro- 263 (def) \\ synopseartikler 21132 \\ tekniske 10 71-73 \\ vs faglige 1071 \\ tosprogede/bilingvale 256 (def), \\ 217-220 \\ spansk-danske almensproglige \\ 5 127-130 \\ standard for emneklassifika- \\ tion $1072 \mathrm{f}$ \\ varedeklaration 15193 \\ vejledning i 33 186-188 \\ se også fagleksikografi; fagord- \\ bøger; leksikografi \\ Ordbogsportalen $3094 \mathrm{f}$ \\ orddannelse 352 \\ i fagsprog 3 68-71, 29275 \\ teknisk fransk \\ udviklingstendenser 3 51-71 \\ hybriddannelser 359 \\ kategorier 3 54-59 \\ afkortelse 356 \\ ex nihilo-orddannelse $355 \mathrm{f}$ \\ leksikalske syntagmer $357 \mathrm{f}$ \\ onomatopoietisk 356 \\ se også afærese; affikser; affiks- \\ oider; apokope; brachygrafi; de- \\ rivation; ellipser; komposita; \\ komposition; konfiksation; lån; \\ leksikon (sprogets); neologi; \\ neologismer; præfiksoider; re- \\ duplikation; sammentrækning; \\ suffikser; suffiksoider; synkope; \\ troncation \\ ordforbindelser \\ faste 35 99-101 \\ frie 35 99-101 \\ klassifikation 35 99-101 \\ kohæsion 35100 \\ kompositionalitet 35 99f \\ valenskonstruktion 35101 \\ variabilitet 35100 \\ ordforråd
}

dansk

størrelse 35 161-180

uendelighed? $9142 \mathrm{f}$

endelighed 9 141-156

test 35 161-180

Ordóñez, S.G.

spansk

komparativer 17 255-257

pseudokomparativer 17 257-260

ordsprog 14 279-283, 25 188, 32

209, 36 77-89

vs idiomer 32 213f, 36 82-87

ordbøger

ordsprogsdominans i forb. m.

idiomatik 25188

top 10-liste 14282

typiske træk 36 79-81

variation/modifikation 36 81f

ordsprogsforskning $\mathbf{3 2} 208$

ordsprogsidiomer 36 83-87

ordstilling $330 \mathrm{f}$

organisationskulturanalyse

og SFL 34 153-155

Orlova-Jermark, Marina

Russisk-dansk juridisk ordbog 24

190-196

orthografisk Lexikon, Et lidet

kritisk anmelderi 19134

ortografi $\rightarrow$ retskrivning

Osborn's Concise Law Dictionary

$256 \mathrm{ff}$

output $3024 \mathrm{f}$

-fokusering $\mathbf{3 0} 26$

comprehensible 3024

pushed 3024

overbegreber

fransk 35214

overfladefilter 224

overfladestruktur 1 154ff, 13 264,

17 144f

oversættelse 831 (def), 12 159, 15

196f, 262-271, 16 221-223, 236-

238, 17283 (def)

bibel- 5 15-33

dansk 
historie 5 17-20

problemer 5 15-33

privat 519

den resen-svanningske $518 \mathrm{f}$

dansk og spansk

tematiske elementer 3 30-43

fagsprogs- 3 29ff, 12 91-108

komposita 8 29-42

målsprogs- 12 104-107

formler

grammatiske $28188 \mathrm{f}$

og fraseologi 35 157f

funktionel 21191

imitativ 21191

komposita $835 \mathrm{f}$

i fagsproglige tekster $829-42$

litterær 15 265f, 18 205-208

maskinel $28188 \mathrm{f}$

vs menneskelig 3 43-46

nyheder 13 235-249

online

programmer 3097

Reverso 3097

Systran 3097

ord til ord- 16221

reklame- 2 149-170

kompetence 2 154f

uoversættelighed 2 151f

strategier 21 191-193

teknisk 28 187-190, 35277

fransk-svensk 35 275-279

fransk-tysk 35 275-279

kulturaspektet 28 179-190, 29 261f

tekstlingvistisk og pragmatisk perspektiv 21 188-194

tema-rema struktur 3 29-49

vs tolkning $17283 \mathrm{f}$

tv- $13236 f$

se også ækvivalens; simultantolkning; tekstning; tolkning

oversættelsesforskning $17283 \mathrm{f}$

norm-orienteret 17283

oversættelsesordbøger

ækvivalenter i oversættelses- ordbøger 2 217-220

eksempler

unificerende 29 327-336

grundlag og løsninger 29 327-336

Oversættelsesportalen 3095

oversættelsesteori 3 317-319, 16

236-238, $17283 \mathrm{f}$

hovedproblemet $\mathbf{1 6} 222$

lingvistisk orienteret 17283

oversættelsesordbøgers 832

Oxford English Dictionary

belæg 117

Oxford, Rebecca

læringsstrategier 3032 (def)

\section{$\mathbf{P}$}

p-tema 35 218, 222

påhængsspørgsmål 1940

pædagogik $\rightarrow$ autonomibegrebet;

fremmedsprogspædagogik; læring;

undervisning; undervisningsdiffe-

rentiering

Palsbro, Lene

jurister og journalister $36186 f$

Paltridge, Brian

genre, frames og akademisk

skrivning 22 192-198

paradigme 28162

Pariserskolen 3 190f

parømiologi 32208

passiv

-konstruktioner 17 151-153

-s- 1 78-80, 143

blive- $178-80,143$

dansk og tysk 1 63-82

i generativ grammatik 2 9-12

medio- $179 \mathrm{f}$

pseudo- 213

reflexiva og passivering $\mathbf{1} 81$

werden- $179 \mathrm{f}$

passiverbarhed

dansk 1 63-82

litteraturen vedr. 170

ikke- 177 
118

manglende $165,69,77 f$

tysk 1 63-82

litteraturen vedr. 1 65-69

og verbalvalens 1 71-76

Pastor, Gloria C.

anvendelsen af para nada 29273

pausekomma 13 319-325

Pêcheux, Michel

diskursanalyse 2210

Pedersen, Christiern

bibeloversættelse 517

Pedersen, K.M.

ordbog vs encyklopædi 14237

Peirce, Charles S.

videnskabelige metoder og kodebegrebet 36188

Perelman, Chaïm epidiktioner 2048

Pérennec, M.-H.

højreudvidelserne i nominalfrasen

15282

nulartikler 15286

Peretti, P.

genitivus explicativus 15283

Peretz, A.S.

reading comprehension in LSP 2

188

Perlmutter, David M.

overfladefilter 224

Perry, J.

semantisk relativisme 2142

persondeiksis 26 120, 36175

persvasion 10105 (def), 2122 persvasive virkemidler $\mathbf{1 0} 105 \mathrm{f}$

Petersen, Hanne

Holberg og europæisk kultur 36183

Petersen, Helle

organisationers troværdighed 34163

Picht, Heribert

begreb og objekt 22191

fagsprog 497 (def)

vs almensprog 389

forskning 1195

terminografi vs fagleksikografi

13 306, 308 terminologi

-lærens forskningsgenstand 15

190

-teoriens historiske udvikling

22190

Pilegaard, Morten

Medicinsk ordbog 14 267-271

netværksbaseret læring 3011

Piotrowski, R.G.

korporas repræsentativitet $\mathbf{1} 231$, 234

Pitzek, Mitar

encyklopædiske angivelser $\mathrm{i}$ ordbøger $2926 \mathrm{f}$

leksikologi vs leksikografi 2924

plagiat 34 266f, 274-276

Platzak, Christer

begrænsende knuder 230

nominale udtryk 492

sproglig økonomi 494

plesionymi 2198

Pogner, Karl-Heinz

erhvervssprog 21141

point of event $\mathbf{3 0} 151$

point of reference $\mathbf{3 0} 151$

point of speech 30151

Politikens Musikordbog

anmeldelse 20 242-244

Politikens Nudansk Ordbog $19143 f$

vs DDO, RO og NET $33157 \mathrm{ff}$

Politikens Retskrivnings ordbog

vs Dansk Sprognævns og

Gyldendals retskrivningsordbøger

$29200 \mathrm{ff}$

Politov, Stefan

korporas repræsentativitet $1231 \mathrm{f}$

polyfoni 20 59-77, 68 (def), 21 26-29

-konfiguration 2128

lingvistisk 20 67-72

polyfoniteorien $19270,2126 f$

polyptoton $18221 \mathrm{f}$

polysemer 2945

polysemi 2945 (def), 46 (fig)

Popper, Karl

argumentation i sproget 2121 
Por muchas razones $\rightarrow$ Danskspank handelsordbog (Por muchas razones)

Porzig, W.

metaforfelter 18231

positivisme $\rightarrow$ logisk positivisme

possibility space $\rightarrow$ mulighedsrum

Postal, P.M.

svag antirepræsentationalisme 2140

postfordisme 4121

Pottier, Bernard

semanalyse 2 88f, $92 \mathrm{f}$

Poulsen, Sven-Olaf

hypotetiske betingelseskom-

plekser 30 141, 143

tysk grammatik 16 252-255

prædikater

forandring 19117

tilstand 19117

prædikatorregel 3 112, 119-121

prædikatorsystem 3120

præfiksering 355

præfiksoider 358

præpositionalfraser 321

postnominale 15284

præpositionsstranding 27118

præsentative konstruktioner 17164

præskription 21100

vs deskription 21 101-107

og leksikografisk praksis 21 107-

116

præskriptiv vs deskriptiv lingvis-

tik 21 101-107

typer af præskription 21107

se også deskription; normproble-

matikken; proskription; sprogrig-

tighed; usus imperans; usus impe-

rium; usus tyrannus

præsuppositioner 13 277, 1931 (def)

faktuelle 2154

præsuppositionsrum 30242

Pragerskolen 3 87f

pragmatik 1067 (def), 15 246f

forskningen 14194

integreret 2121 tekst- $1122 \mathrm{f}$

kohærens 1 122f

universal- $5115 \mathrm{f}$

Prebensen, Henrik

semantiske roller 19 116ff

Preisler, Bent

engelskpåvirkningen i dansk 26

190-194

Prince, Violaine

informatikterminologi $363 \mathrm{f}$

privat disposition 5117 (def), 117f

PRO 2 27-29

procedens $333 \mathrm{f}$

processkrivning $14205 \mathrm{f}$

procesverber $17254 \mathrm{f}$

proformer 19 289-294

programmeringssprog $279 \mathrm{f}$

promulgationsformular 5116

pronominelle kataforer 21 217-222

propositioner 19 117, 20106 (fig)

karakteristika 20 48-50

proprier 26121

proskription 21 107, 33 186-188

og leksikografisk praksis 21 107-

116

se også deskription; normproblematikken; præskription; sprogrigtighed; usus imperans; usus imperium; usus tyrannus

prototypikalitet 2087

proximity search $\mathbf{3 0} 87$

pseudo-affikser 358

pseudo-suffikser 358

pseudohomografi 12208

pseudokomparativer 17257 (def)

spansk 17 257-260

pseudopassiver 213

psykologi

kognitiv 3018

Pütz, H.

fremmedsprogstilegnelse 13337

purisme

dansk 15 261f, 26191

i EF-regi 13313

IT-sprog 5147 
jagtsprogsleksikografi 20248 fællesskandinavisk enhedsstræv 21 100f

fransk 353,61

juridisk sprog 4130

se også dansk (engelsk indflydelse på)

Pustejovsky, J.

handlingsstruktur 21 56-58

semantisk lukkethed 2162

Puuronen, Nina

dynamiske begreber og referenter 22191

\section{Q}

q-tema 35 218, 222

quaestio

begrebet $\mathbf{3 0} 130$

Quaestioteorien 30 130-132

que-til-qui reglen 232

Quintin, H.

nominalfraser

i ytringsenheder uden verbal

$$
15288
$$

postnominale præpositionalfraser 15284

\section{$\mathbf{R}$}

Rabuse, G.

reklamesprog 2152

radiærordbog, dansk 1 37-41, 41 (fig)

radiosprog 6 189-193

vs talesprog 6190

Ralph, Bo

fagsprog $376 \mathrm{ff}$

rammer 1 87, 2 106f, 163, 22192 -

198, 194 (def)

analyse $2163 \mathrm{f}$

interaktionelle 22195

rammestruktur (leksikografisk) 21131

Rangnes, Odd K.

terminologiarbejde 22191

ranking 3087
Rask, Kirsten

stilistik 17 261-266

Rasmussen, Gitte

lingua franca-samtaler 20148

Rasmussen, Kirsten Wølch

tekstkorpora 5 123-126

Rasmussen, Lone Schack

in memoriam 199

Rasmussen, Niels R.

læringstyper 3065

Rasmussen, Poul Bøggild

in memoriam 199

Rasmussen, Tage

læringstyper 3065

Rastier, François

betydning 298

ensemble de définition 289

generalitet 14159

isotopibegrebet $154 \mathrm{ff}$

kritik af 159

semantik $146 \mathrm{ff}$

mikro- $14150 \mathrm{f}$

veri-konditionel 285

semer 2 93f, 14 152f

begrebet 1118

specifikke 14155

realdefinitioner $\mathbf{2 8}$ 158, 170

vs nominaldefinitioner 28158

realisme

vs diskursanalyse 4 118-120

realitetsrum 26 139, 30 134, 149ff

reality space $\rightarrow$ realitetsrum

redeartikler 261 (def), 61f

se også lemmaopstilling; niche-

artikler; sorteringsprincipper

reduktionisme $\mathbf{2 8} 160 \mathrm{f}$

reduplikation 356

reference 20266 (def), 21 154f

-identitet $14265 f$

delidentitet 14266 (def)

-relationer 14 260-264, 30242

deskriptive 14 260-263

ekstensionelle 14 260-263

identitets- 14 260-264

kausale 14 260-263 
anaforisk 4 91, 20268 (def)

arbitrær 2 27f

begrebet 14264

ekstralingvistisk 21154

endoforisk 20268 (def), 21155

exoforisk 20268 (def), 21155

intern 1 48, 21155

kataforisk 20268 (def)

kontrolleret $227 \mathrm{f}$

leksikalsk 14203

obviativ 1181

proksimativ 1181

pronominal 14203

situationel 21154

tekst- 26140 (def)

tekstekstern 20268 (def), 21155

tekstintern 20268 (def), 21155

tekstuel 21155

fagtekstuel 14 259-266

refleksivitet 20142

reformuleringer $14145 \mathrm{ff}$

cad- 14 145-164

mikrosemantiske relationer i

14 150-161

fransk

skriftlig 14145

ikke-parafraserende 14148

parafraserende 14148

produktive 14160

reproduktive $\mathbf{1 4} 160$

semantiske relationer i 14 145-164

registeranalyse 312,34159

registeropskrift 34 157-159

registre 34 156-159

Regnskabsordbogen dansk-engelsk

anmeldelse 34 279-283

reguleringsteorien $\mathbf{4} 121$

Reiben, Claus

virksomhedsstrategi 13 344f

Reich, Ebbe Kløvedal

bibeloversættelse 524

Reichenbach, Hans

tid i engelsk 30151

Reinhart, Tanya

definition af styring $\mathbf{1} 167$
Reiß, Katharina

oversættelse 2 149, 3318

reklame- $1156 \mathrm{ff}$

tekstsortkonventioner 15290

reklamer 2160 (def), 2047 (def)

afsender-modtager-forhold 2165

appelfunktion 2158

argumentation og retorik $2047 \mathrm{f}$

den argumentative teksttype $\mathbf{2 0}$

41-57

begrebet 2150

direkte 2 159f

som diskursgenre 2 163-169

emotionel appel 2 160f

kampagneslogan 2050 (def)

maskering 2161

som operativ tekst $2157 \mathrm{f}$

oversættelse 2 149-170

kompetence $2154 \mathrm{f}$

persuasionsstrategier 2 160f, 167

skjulestrategien 2167

teksttypologi 2156

Reiß' teksttypologiserings-

model 2 157ff

typologi 2153

uoversættelighed 2 151f

reklamesprog 2 157f, 10 104f

forskningen 10104

rektion 1930 (def)

rekurrens 36169 (def), 169f

relationsmaksimen $\rightarrow$ konversations-

maksimer

rema

delt $333 \mathrm{f}$

tema- 13258 (def)

oprindelse $13257 \mathrm{f}$

struktur 3 29-49

rematisering 13260

fokus- 342

repræsentativer 26 123, 127-133

reproducerbarhed

ved idiomer 3678

Resen, Hans Poulsen

bibeloversættelse 518

retlige aktører 36182 
retningskontrast 2197

retorices partes 36220

retorik 13 371-373, 14 245-248, 23

239-241

anvendt 36 219-226

historie $20244 \mathrm{f}$

stemmeflyttende 14247

stemmesamlende 14247

se også argumentation;

skrivepædagogik; stilistik

retskrivning

anbefalelsesprincippet 31163

dansk 11 143-146

forbudsprincippet 31162

majonæse-krigen 12196

sprogbrugsprincippet 29199

traditionsprincippet 29199

vildledningsprincippet $\mathbf{3 1} 162$

se også sproglov (dansk); sprogpolitik

Retskrivnings ordbog (Gyld) 19143

vs Dansk Sprognævns og

Politikens retskrivningsordbøger $29200 \mathrm{ff}$

Retskrivningsordbogen (DS) 19143

vs DDO, NDO og NET 33 157ff

fleksionsangivelser 21 95-116

vs Gyldendals og Politikens

retskrivningsordbøger $29200 \mathrm{ff}$

immuniseringsstrategi 29212

kritik af 29 199-215

lemmahuller 29203

lemmalig 29203

lemmaselektion

kriterier 29203

nye opslagsord 29202

normproblematikken 21 95-116

retskultur 36188 (def)

dansk 36 181-189, 191-196

og fransk 36185

engelsk ret 14225

europæisk 36 181-189, 191-196

EMD's og Højesterets begrund-

else af domme 36185

kirke- og religionsret 36186 i historisk og nutidigt perspektiv

$36183 f$

kommunikationsproblemer 36

184-186

termen 36187

retskulturforskning 36187

Retsplejeordbog

anmeldelse 9 193-196

retsregler 5113 (def)

Aftalelovens 5 117-121

som kommunikative handlinger 5

113-121

konstitutive 5 117, 119f

regulative 5 117, 119

Searles regelbegreb 5 117-120

som sproghandlinger 5 113-116

se også deklarationer; direktiver;

ekspressiver; exercitiver;

forholdsnormer; kommissiver;

kompetencenormer;

promulgationsformular;

repræsentativer; sproghandlinger;

verdiktiver

Reverso 3097

rhetorical techniques 3 16-18

Richey, Michael

usus tyrannus 21103

Rieger, Burkhard

korporas repræsentativitet $\mathbf{1} 230$

Riemsdijk, Henk C. van

begrænsende knuder 230

kasus 1172

rigsmål

vs særsprog 12197

rigsmålsrim 35154

Riiber, Theis

aktiv-passiv-teori 26156

Dansk-tysk teknisk ordbog

(Clau) 1071

Ripfel, Martha

ordbogsanmeldelser 432

Risager, Karen

SIGLES $16265 \mathrm{f}$

Rizzi, Luigi

begrænsende knuder 230 
$\mathrm{RO} \rightarrow$ Retskrivningsordbogen

(DS)

Roald, Jan

definitioner 494

fagsprog 3 77, 91, 4 87, 94f

vs terminologi $393 \mathrm{f}$

tekster 488

Robinson, Richard

essens 28159

Rørbech, Lone

retorik 14 245-248

Rojo, Guillermo

ARTHUS 29274

Roksvold, Thore

anvendt retorik 36 219ff

Roman, André

modus-res teori 12162

Rosbach, Poul

aktiv-passiv-teori 26156

Rosch, Eleanor

begreber 391

prototypeteorien 22194

Rosenbohm, Hans-Otto

Dansk-tysk ordbog (Munk) 10

133-141

Rossi, Mario

fokalisering 13265

Rossman, Tammi

SLA 3019

Roulet, Eddy

teksttyper

kritik af J.-M. Adam $2036 f$

Rousing, Anders

dansk-engelsk medicinsk glossar

1239

Rubins profilvase 2937 (fig)

se også Wittgensteins kaninand

Russell, Bertrand

begreber 28160

russisk

leksikaliseringsmønstre 35 232-234

old-

benævnelsesstrategier 35219

betydninger 35 221-229

betydningspotentiale $35219 \mathrm{f}$ leksikaliseringsmønstre 35 221-

229

vs moderne 35 230-236

benævnelsesstrategier $35235 \mathrm{f}$

verber

genus $35219 f$

det verbale leksikon 35 219-229

rets- og politisprog 24 190-196

Russisk-dansk juridisk ordbog

anmeldelse 24 190-196

rutineformler 17 157-161, 18159

(def)

Ruus, Hanne

et dansk korpus $1232 \mathrm{ff}$

Rydstedt, Rudolf

retorik 13 371-373

rykkerskrivelser 15224

Rytter, Jens Elo

EMD's og Højesterets begrund-

else af domme 36185

\section{S}

S-strukturer 1158

S-udtryk

intuitiv semantik 27 102-105

syntaks 27 99-134

Sacks, Harvey

konversationsanalyse 20142

Sæbøe, Randi

terminologi 22 189-192

og sociolingvistik/sociologi 22 191

sætninger

dansk vs spansk

struktur 333

økonomi i udtryksformen 3

$37-40$

eksistens- 331

emne 5138 (def)

informationsstruktur på sætnings-/ytringsniveau 13 251-278

kløvning

spansk 29272 


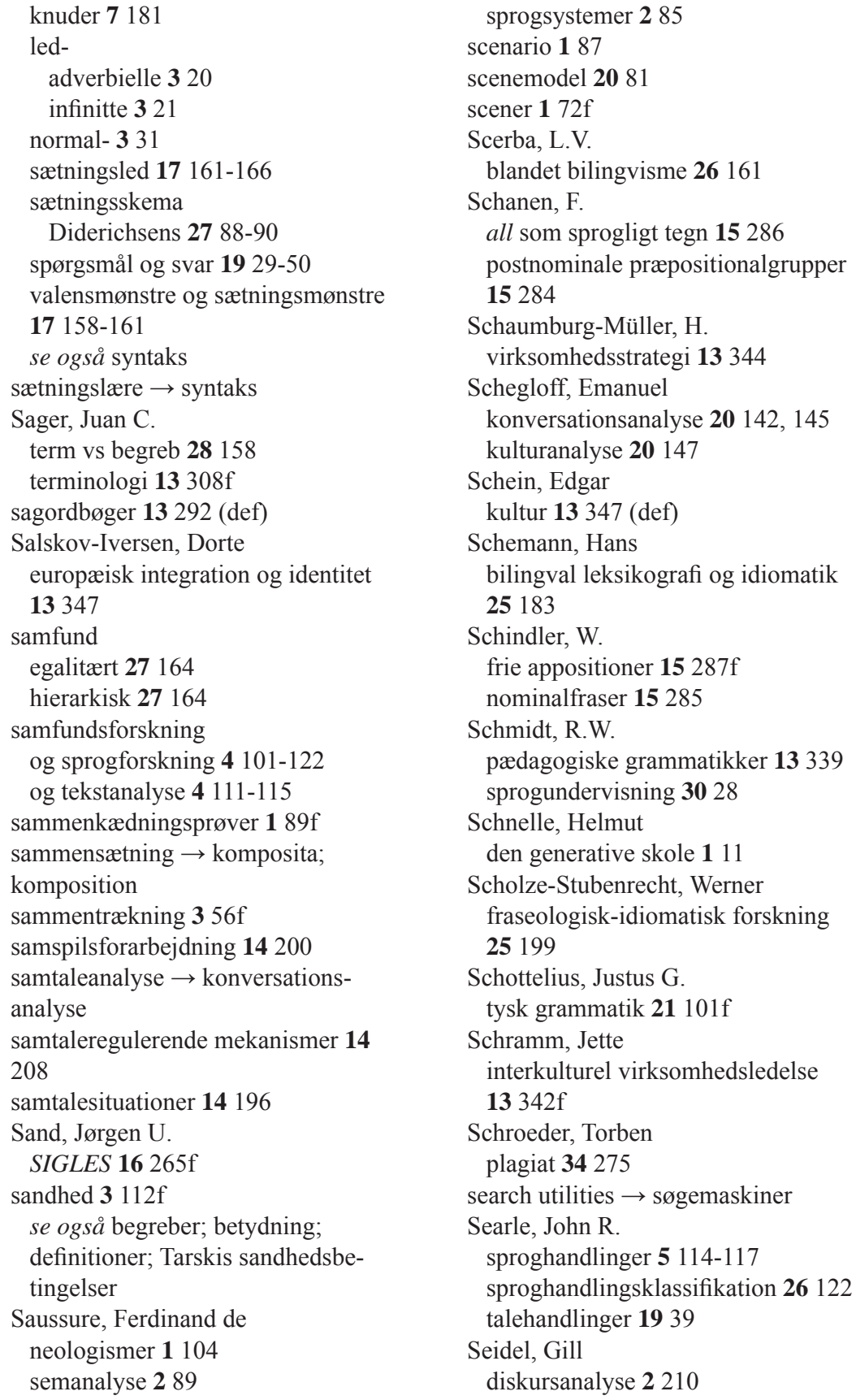

sprogsystemer 285

scenario 187

scenemodel 2081

scener $172 \mathrm{f}$

Scerba, L.V.

blandet bilingvisme 26161

Schanen, F.

all som sprogligt tegn $\mathbf{1 5} 286$

postnominale præpositionalgrupper 15284

Schaumburg-Müller, H.

virksomhedsstrategi 13344

Schegloff, Emanuel

konversationsanalyse 20 142, 145

kulturanalyse 20147

Schein, Edgar

kultur 13347 (def)

Schemann, Hans

bilingval leksikografi og idiomatik 25183

Schindler, W.

frie appositioner $15287 \mathrm{f}$

nominalfraser 15285

Schmidt, R.W.

pædagogiske grammatikker 13339

sprogundervisning $\mathbf{3 0} 28$

Schnelle, Helmut

den generative skole 111

Scholze-Stubenrecht, Werner fraseologisk-idiomatisk forskning 25199

Schottelius, Justus G. tysk grammatik $21101 \mathrm{f}$

Schramm, Jette interkulturel virksomhedsledelse $13342 \mathrm{f}$

Schroeder, Torben plagiat 34275

search utilities $\rightarrow$ søgemaskiner

Searle, John R. sproghandlinger 5 114-117 sproghandlingsklassifikation 26122 talehandlinger 1939

Seidel, Gill diskursanalyse 2210 
Seidelin, Anna Sophie bibeloversættelse 519

Seidelin, Poul

bibeloversættelse 519

sekventialitet 2023

struktur $2043 \mathrm{f}$

se også tekstsekvenser; tekstty-

pologi

Seleskovitch, Danica

tolkeforskning 17284

Selinker, Larry

fagsprog 313

intersprog 3017 (def)

Selsøe Sørensen, H.

maskinoversættelse 15268

selvbillede

begrebet $26123 \mathrm{f}$

interpersonelt 26 123, 126-133

intrapersonelt 26 123, 126-128, 132f

semantemer 295

semantik 5 153f, 15 246f

analysemetoder

interlingval sammenligning 2105

kontekstuel analyse 2105

substitutionsprøven 2105

udfyldningstesten 2105

argumentativ $\mathbf{2 1} 17$

faktorer 35122

realisering/ikke-realisering 35

$124 \mathrm{f}$

faseverber 29 59-62

restriktioner 29 65-67

forskningstraditioner

semantisk idealisme 2141

semantisk konstruktivisme 2142

semantisk realisme 2141

semantisk relativisme 2142

situationssemantikken 14167 -

188, 2142

stærk antirepræsentationalisme

2140

svag antirepræsentationalisme

2140

generativ 220

instruktionel 2117 instruktions- 21 58-64

interpretativ $154 \mathrm{ff}$

isotopi 1 45-61

indholdsform vs indholdssubstans

147

kritik af begrebet $152-54,59$

kasus $175 f$

katastrofeskemaer 19 118-128

kognitiv 23174

kritik af 23 175-179

kompleksitet 21 39-65

komponentiel 2 90-97

kontrast 2197

leksikalsk 2 77-107, 193-200, 21

24-26

mikro- 14150

net 2106

relationer

ekstralingvistiske 14161

horisontale 14 154-159

i reformulering 14 145-164

vertikale 14 154, 159-161

roller 17 155-158, 19 115-129,

20109 (fig)

instrumentrolle 19 123-127, 125 (def)

se også agent; locus; topoi

S-udtryk 27 102-105

situations- 14 167-188, 2142

strukturel 1 105f, 2 77-107

tekst- 1 124-131

kohærens 1 124-131

teori 21 40-43

se også forskningstraditioner (semantik)

transfereringsregler 35123

transparens 35142

typologi 21 45-47

valens 1 71-76

veri-konditionel 2 84, 5154

videnskabelighed (semantik-

kens) 2 104f

XP-udtryk 27 93f

se også feltteorien

semasiologi 


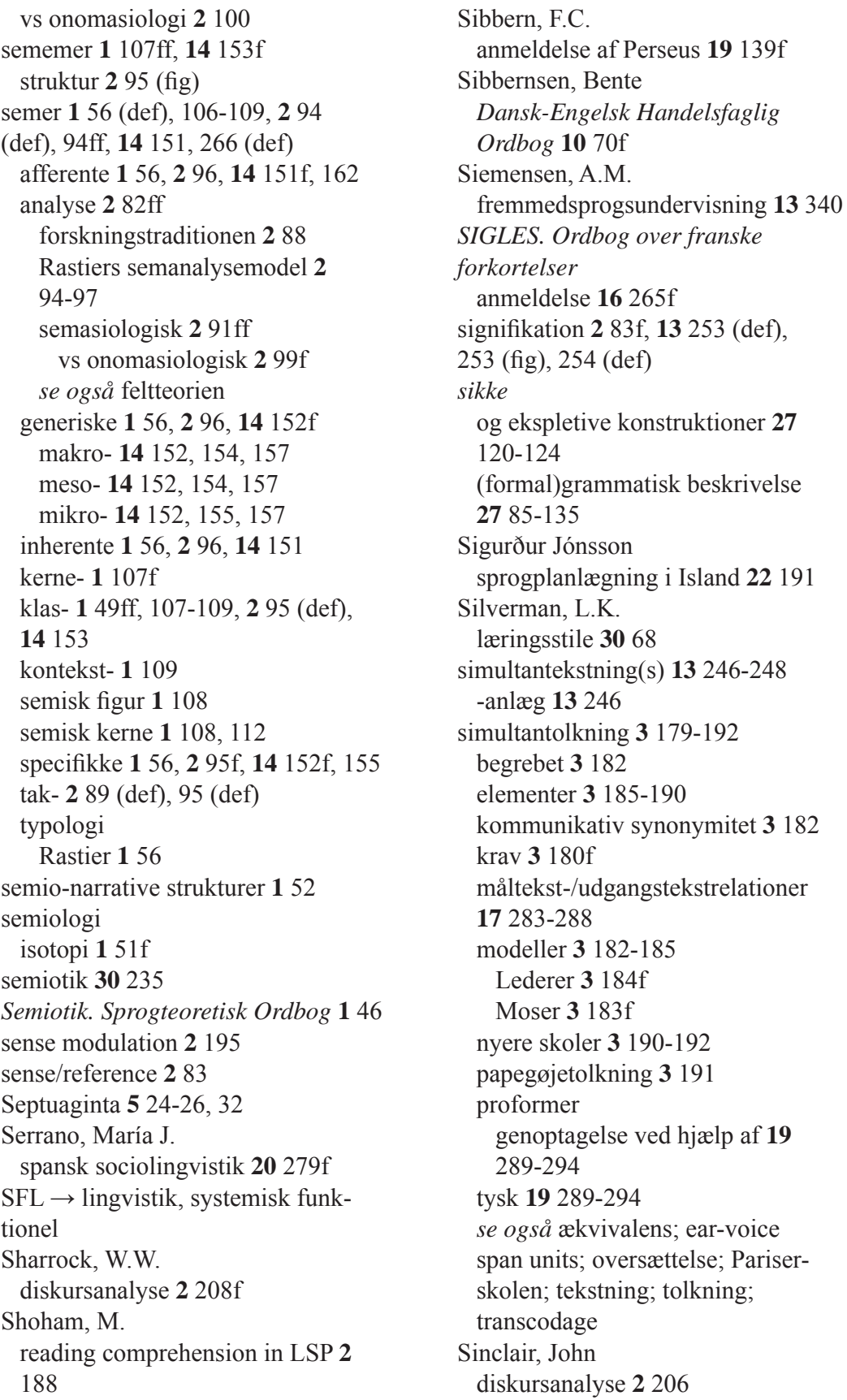


kollokationer 35108 (def)

Sinn 282 (def), 14151

Sinnkontinuität 36160

situationer 14 169f

samtale- 14196

i sprog 14 167-188

typer 2 166, 21 63f, $35215 f$

ytrings- 14 172-178, 183f, 21

59-63, 59 (fig)

situationsfundament 17163

situationssemantik 14 167-188, 2142

situationsteori 14167

Skiba, R.

tysk som andetsprog $13335 \mathrm{f}$ skrift

vs tale 6191

skrivepædagogik 22 172-175

akademisk skrivning 22 192-198

processkrivning $14205 \mathrm{f}$

skriftlig fremstilling 14 238-244

skriveværksteder $14205 \mathrm{f}$

se også retorik; stilistik

Skytte, Gunver

oversættelse 18206

Skyum-Nielsen, Peder

fyndord 14 279-283

SLA

forskning $\mathbf{3 0} 22$

og intersprog 30 16-21

Slavgorodskaja, L.V.

fagsprogsforskning $1206 \mathrm{f}$

slavistik

12. Nordiske Slavistmøde 6 203206

slavofile 6204

slogans 14 279-283

top 10-liste 14282

Šmelev, D.N.

fagsprogsforskning $1205 \mathrm{f}$

funktionaltyper 1202

Smith, Viktor

Russisk-dansk juridisk ordbog 24 190-196

sociale variabler $\mathbf{1 5} 211 \mathrm{ff}$

autoritet $\mathbf{1 5} 211 \mathrm{ff}$ distance $15211 \mathrm{ff}$

Søderberg, Anne-Marie

europæisk integration og identitet

13346

interkulturel kommunikation $\mathbf{1 3}$

340-348

kultur 20151

søgemaskiner 30 80-87, 83 (fig)

Alexa 3081

Atomica 3081

Google 3080

meta- $\mathbf{3 0} 81$

varianter

katalog 3080

robot $\mathbf{3 0} 80$

Yahoo 3080

se også interfacesprog; search

utilities

søgesprog $\mathbf{3 0} 85$

søgning

avanceret $\mathbf{3 0} 85$

Google 3085

se også proximity search; ran-

king; tekstmining; trunkering;

wildcards

Sørensen, Finn

dobbelt lokativ 19126

semantiske roller $19116 \mathrm{ff}$

Sørensen, Knud

Dictionary of Anglicisms in

Danish 21 194-198

engelsk i dansk 16 238-241

solliciting response 27 144f

somatoidiomer 25175

Sørensen, Torben Berg

samtaleanalyse 4 139-143

sorteringsprincipper

alfabetiske 2 60, 13364

vs systematiske 13 370f

nichestruktur 261 (def)

radiære 137

redestruktur 261 (def), 61f

retrogradalfabetiske 137 
se også alfabetisering; ord-forord-metoden; tegn-for-tegnmetoden

Spang-Hansen, Ebbe modus og modalitet 1140

spansk

adjektiver 29 290-299

anvendelsen af para nada 29273

diminutiver $26121 \mathrm{f}$

diskursmarkøren o sea 29274

fraseologi 17 266-268

grammatik $27211 \mathrm{f}$

basis- 7 175-178

handelssprog 23 242-244

hypokoristika $26121 \mathrm{f}$

indikativ $20278 \mathrm{f}$

vs konjunktiv $29269 \mathrm{f}$

konjunktiv $20278 \mathrm{f}$

nominalsyntagmer

intern struktur 29 291, 294

referenceforhold 30 237-244

objekter

direkte vs indirekte 29271

dobbeltrepræsentation af $\mathbf{2 9} 275$

ordbøger

spansk-danske

almensproglige 5 127-130

præference for fuldsyntagmer 340

sætningskløvning 29272

sætningsstruktur

vs dansk 3 29-49

sproglige sammenligninger $\mathbf{1 7} 255 \mathrm{f}$

substantiver 29 290-299

verber 20 277-280

caer's semantik 29273

imperfecto 17 253-255

indefinido 17 253-255

tempora i fortid indikativ 17

251-255

vokativ

i pragmatisk-funktionelt perspektiv 26 119-135

Spansk-dansk ordbog (Gyld)

anmeldelse 26 151-163 vs Spansk-dansk ordbog (Munk)

5 127ff, $7110 \mathrm{ff}$

Spansk-dansk ordbog (Munk)

vs Spansk-dansk ordbog (Gyld) 5

127ff, $7110 \mathrm{ff}$

specialfokus 13 261-271

specialordbøger 10 73-93

specificering 14 159f, 164

speech acts $\rightarrow$ talehandlinger

spørgsmål

ekko- 217

enigheds- $1939 \mathrm{f}$

enten-eller- 1939

ja/nej- $1939 f$

påhængs- 1940

og svar 19 29-50

dansk vs italiensk 19 29-50

X- 1939

spørgsmål-svar-konstruktionen 19

44-50

spor $1155 \mathrm{ff}$

that- 224

sporteorien 1155

Sprechzeit 30151 (def)

sprog

-opfattelse

grammatisk vs stilistisk 1200

terminologiteoriens 3 99-103

almen- 15293 (def)

og begreb $28163 \mathrm{f}$

betydningsmæssig underbe-

stemthed 29 44-47

dødt vs levende 9142

E- 233

erfarings- 2215

formelle $278 \mathrm{ff}$

vs naturlige $279 \mathrm{f}$

fremherskende forestillinger om

$27213 f$

I- 233 (def)

som kollektivbegreb $385 \mathrm{f}$

og kultur 3229 (fig)

kunstige $388 \mathrm{f}$

som mængdebegreb $385 f$

niveauer 17 144-148 
paradigmer 17 151-154

programmerings- $279 \mathrm{f}$

radio- 6 189-193

vs tale- 6190

reklame- 2 157f, 10 104f

forskningen $\mathbf{1 0} 104$

relationen mellem sprog og

genre 22197

rigsmål

vs særsprog 12197

sproglig folkeoplysning $27213 \mathrm{f}$

sproglig strukturering

vs kognitiv strukturering 17148

det sproglige tegn 17 142f

struktur og substans 17 148-150

sub- 3 83, 10104

teorien $\mathbf{1 0} 104$

som system $34156 f$

systembeskrivelses- 2 79f (fig)

og tænkning 3117

tale-

vs radio- 6190

som tekst 34156

og verden 20265

videns- 2215

se også erhvervssprog; fagsprog;

kommunikation; kultur; terminologi

sprogbeskrivelse 18,2 112f

ekspressiv-grammatisk $2115 \mathrm{f}$

formel 2 78-82

kriterier for vellykkethed $2114 \mathrm{f}$

teoretisk-epistemologisk 2115

se også grammatik

sprogforandring

engelsk i dansk 16 238-241, 21

194-198, 26 190-194

flerordsenheder $35156 \mathrm{f}$

og subkulturer 26 190-194

se også lån; neologi; neologismer

sprogforskning $\rightarrow$ lingvistik

sproghandlinger 2 165, 167f, 3238 ,

5 113-121, 14 194-196, 26122

(def), $122 \mathrm{f}$

handlingsregulerende 5113

institutionelle 5116 institutionelt bundne 5115

klassifikation

Austin 5114

retsregler 5 113-116

typer 14208

vellykkethedsbetingelser 5 114f,

120

se også deklarationer; direktiver;

ekspressiver; exercitiver; inter-

views; kommissiver; promulga-

tionsformular; repræsentativer;

retsregler; verdiktiver

sprogindlæring 3 11-14

computermediets

differentieringspotentiale 30 13-34

fremmedsprogstilegnelse

psykolingvistiske og didak-

tiske aspekter 13 332-340

inputforarbejdning 3022

læringsproces 3020

intersproglig

feedback 3029

model 3021 (fig)

inputorienteret 3022 (fig), 22f,

$26 f$

kumulativ 3020

linær $\mathbf{3 0} 20$

outputorienteret 3022 (fig), $26 f$

syntetisk vs analytisk 3 11-14

termen sprogindlarer $\mathbf{3 0} 16$

sprogkompetens 112

som ansættelsesparameter $\mathbf{1 3}$

281-289

lingvistens 1 10, 12

se også introspektion; kommuni-

kation; multispektion

sproglig økonomi 4 92ff

sproglige tests $\mathbf{1}$ 13-16

sproglov

dansk 29 198-200

sprognormering

funktion 12197

sprogordbøger 13292 (def)

sprogpolitik 31 135-164, 136 (def),

167-170 
dansk 31 135-164

i offentlige institutioner 31

143-148

Danmarks Radio 31 144-146

Give Kommune 31 143f

Statens Information 31 146-148

i private virksomheder 31 148-159

Grundfos 31 152-159, 167-170

TDC 31 150-152

Topdanmark 31 148-150

sprogloven 29 198-200

inden for EU 31138

inden for FN 31138

fransk

sproglovgivning $353 \mathrm{f}$

generel 31 137-141

inden for Nato 31138

specifik 31 137, 141-164

sprogspecifik 31137

sprogudformning $3122 \mathrm{f}$

termen $\mathbf{3 1} 136$

sprogrigtighed 12 196-198, 21 95-116

se også deskription; normproble-

matikken; præskription; proskrip-

tion; usus imperans; usus imperium; usus tyrannus

sprogspil 28163

sprogsystem $2101 \mathrm{ff}$

sprogtypologi 17 107-109

sprogudvikling $\rightarrow$ sprogforandring

sprogundervisning

og IT 30 13-34

sprogfærdighedsniveauer 30 43-45 sprogfærdighedsområder 30 45-47 se også fremmedsprogsundervisning; sprogindlæring

sprogvidenskab $\rightarrow$ lingvistik

squinting grammar 1970

stabilitet

ved idiomer 3678

staccato-tekstning 13248

Stage, Lilian

fraseologiske somatismer 35157

Stahel, Annie

datalingvistik på HHK 13305
Statens Information

sprogpolitik 31 146-148

stavelser

dansk 9 143ff

strukturen 9 143ff

Steensig, Jakob

danske og tyrkiske gruppesam-

taler $13357 f$

turopbygning på dansk vs tyrkisk 20149

Sterck, Goedele De

indikativ vs konjunktiv i spansk

29269 f

stereotypi 2105

Steube, Anita

passivforskningen 1 68-69

stil 1200 (def), 15247

funktional- 1 201-204

makro- 1203 (def)

mega- 1203 (def)

mikro- 1203 (def)

stilistik 1 198-207, 16 245-252, 17

261-266, 261 (def), 18 216-226

deskriptiv 17 261-266

detektivarbejde 17261

distinktiv 17261

figurer $18220 \mathrm{f}$

funktional- 1199

normativ 17261

skønlitterær $1199 f$

sprogets 1 199-200

talens 1 199-200

vestlig vs østlig 1 198-207

Vinogradovs tre stilistikker 1

199-201

Stoltze, Radegundis

nominaltemaer 336

teksttypologisering 2162

Stora fula ordboken (slangordbog) anmeldelse $23232 \mathrm{f}$

Strandvik, Ingemar oversættelsesuddannelse ved Stockholms Universitet 22191

Strevens, Peter

fagsprog 313 
strukturalisme 14 221, 31 211-213

vs økolingvistik 14221

strukturbevarende transformation

$1153 \mathrm{ff}$

strukturer, leksikalske 2 86-90

Stüber, $\mathrm{H}$.

informationsstyring 13305

Stutterheim, C. von

Quaestioteorien 30130

tekstuelle strukturer $30130 \mathrm{ff}$

styring 1167 (def), 167f

behørig 1168 (def), $168 \mathrm{f}$

Subirats-Rüggeberg, C.

spanske tekstkorpora $29271 \mathrm{f}$

subjekt 17 162-165

logisk $15251 \mathrm{f}$

referenceomfang 29272

subjektrestriktion 222

sublemma 265 (def)

subsprog 3 83, 10104

subsprogsteorien 10104

substantiver 17 240-243

adverbiers modificering af $\mathbf{2 9} 296$

i spansk 29 290-299

se også nominaler

substantivsyntagmer 3 37-40, 20

266-268

substitution

som kohæsionsskabende middel

36177

subsystemer, leksikalske $2102 \mathrm{f}$

suffikser

pseudo- 358

suffiksering $354 \mathrm{f}$

suffiksoider 358

superstrukturer 20 63-65, 36162

surveys

i lingvistiske undersøgelser $\mathbf{2 7}$

201-209

Suzuki, Masako

dansk-japansk fraseologi 35158

Svane, Hans

bibeloversættelse 518

svar

adækvate 19 44-48 ikke-adækvate 19 48-50

og spørgsmål

dansk vs italiensk 19 29-50

Svensén, Bo

kollokationer 35 105f

Nordisk leksikografisk ordbok 20

235-242

terminografi $\mathbf{1 3} 308$

svensk

dansk grammatik for svenskere

24 184f, $26168 \mathrm{f}$

fagtekster 14 259-266

idiomer

semantisk variation 35 119-132

kongruens $14248 \mathrm{f}$

oversættelse

teknisk

fransk-svensk 35 275-279

syntaks $12184 \mathrm{f}$

Swain, Merrill

output 3024

syllogisme 2045

synkope 356

synkroni

to slags 1970

synonymi 2 197, 3114

kommunikativ 3182

kontekstuel 2124

ifølge terminologilæren 3109

synspunkt 2068

vs lokutør 2068

syntagmer 5137 (def)

leksikalske $357 \mathrm{f}$

nominal- 17 239-243, 20 265-268

spansk

intern struktur 29294

referenceforhold 30 237-244

syntaks og semantik 15 281-289

tilføjelser til 15285

tysk 15 281-289

assymetri 15282

i ytringsenheder uden verbal

15288

polyleksikalske 25 173-175

substantiv- 3 37-40, 20 266-268 
syntaks

artikel-

i italiensk 20 264-269

faseverber

restriktioner 29 65-67

fundamentpladsen 17 162-166

funktionel 5 137-142

generativ

teori 1 153-184, 2 9-33

H.C. Andersens eventyr $18205 f$

konstruktioner

endocentriske 5139

exocentriske 5139

præsentative konstruktioner 17164

S-udtryk 27 99-134

svensk 12 184f

tekst- $1123 \mathrm{f}$

kohærens 1 123f

valens 171

valensmønstre og sætningsmøns-

tre $17158-161$

X-bar- 1 159-161

XP-udtryk 27 90-99

funktioner 27 111-120

se også sætninger

synteseregel 18

systembeskrivelsessprog 2 79f (fig)

systemteori 28 164-168

det luhmannske 28 165-167

kompleksitet 28166

og terminologisk teori 28 167f

Systran 3097

Szabo, H.

nominelle konstruktioner $\mathbf{1 5} 284$

\section{$\mathbf{T}$}

tælle som-mekanismen 29 42-44

Takeda, Katsuaki

variation/modifikation af ordsprog $\mathbf{3 6} 81$

taksemer 289 (def), 95 (def)

taksonomi 2196

taksonomiske hierarkier 2 195f

tale 1200 (def) vs skrift 6191

talehandlinger 19 39-41

talemåder 32 207f

begrebet 25180

termen 35158

Talemåder i dansk. Ordbog over

idiomer

idiomer i 25 172ff

talesprog

vs radiosprog 6190

tale vs skrift 6191

taletidspunkt $\rightarrow$ Sprechzeit

Tarp, Sven

anmelderi/Orlando Galindos

fagordbøger 19140

anmelderiets nyttesløshed? 19174

brugerbehov

objektive vs subjektive 21125

fordelingsstruktur 21135 (def)

begrebet 21132

handelsordbøger 20 189, 191

IFF Fagordbog 1069

ordbøgers underfunktioner 21125

ordforbindelser og kollokationer

35106

Tarski, A.

semantik 2146

semantisk realisme 2141

Tarskis sandhedsbetingelser 284

TAS $\rightarrow$ argumentation

Tatillon, Claude

reklameoversættelse 2151

Tauli, Valter

sproglig økonomi 492

Tausen, Hans

bibeloversættelse 5 17f

TDC

sprogpolitik 31 150-152

tegn

det sproglige 17 142f, 148

tegn-for-tegn-metoden 260 (def), $60 \mathrm{f}$

tegnbegreber 3102

Teknisk Ordbog (L\&H) 16267

anmeldelse 9 197-204

se også Dansk-Engelsk Fagord- 
bog (L\&H)

teknisk sprog 1071

begrebsdannelse 28 184-187

fransk

orddannelse 3 51-71

tekniske tekster

funktion 28 181-183

terminologisering 28 184-187

tekniske ordbøger 10 71-73

vs faglige 1071

tekno-fetichisme 309

teknolekt 3 79, 14253 (def), 255f,

15291 (def)

vs dialekt 385

vs modersmål 385

vs sagsprog 14254

vs sociolekt 385

teknologioptimisme 30 7-8

tekst 147 (def), 121-131, 225 (def),

2205 (def), 4 88, 13 255, $2020 \mathrm{f}$

-kvalitet 14 203-206

-mining 3087

-organisering

kulturelt betingede forskelle i

28 189f

-sammenhæng 1 86-88

-strukturer 152

bi- 30 129-157, 137 (def), 149

(def)

funktioner 30 138-156

evidentielle inddragelser 30

145-148

fiktionsbeskrivelser 30144

generiske konstateringer 30

$139 f$

hypotetiske påstande 30 140f

irreale forestillinger $30141 \mathrm{f}$

konstitutive konstateringer

$30144 f$

mulighedsantagelser 30

142-144

reale konstateringer 30

149-156

Stutterheims $30131 \mathrm{f}$

definition ny 30 132-137

Stutterheims 30130

hoved- 30 129-157, 137 (def), 149 (def)

hovedstrukturytringernes

tidslige indordning $\mathbf{3 0} 151 \mathrm{f}$

Stutterheims 30 130f

-undersøgelser 1 16-17, 22

funktionelle roller $14203 f$

global opbygning 14 203-206

heterogen 20 15, 44

homogen 2015

hyper- 30 88, 36158 (def)

kohærens i 36 157-178

kohæsion i 36 157-178

vs lineær 36 159, 161, 164,

$169,171,177$

ikke-autentisk 1 121-131

indholdsorienteret beskæftigelse med 1128

lineær

vs hyper- 36 159, 161, 164, $169,171,177$

organisationsplaner $2042 \mathrm{f}$

og samfundsforskning 4 101-122

sprogorienteret beskæftigelse

med 1128

teknisk

funktion 28 181-183

tekstanalyse 1 121-131

brugs- 20 255-259

kumulativ 489

og samfundsforskning 4 111-115

sproglig 19 268-279

tekstemer 35136

tekstkohæsion $\rightarrow$ kohæsion

tekstkorpora 1 17-21, 211 (def),

229-236

brugsfunktion 1211

delmængde 1212

etablering 1 211-214

fagsproglige 15 184-186

genteknologi 15185

jura 1 209-227, 4 127-136, 5

123-126, 15185 
vs sagsproglige 15186 grundmængde 1212,230 homogenitetsproblemet 1233 ikke-maskinlæsbare 118 korpusanalyse 1212 korpusbrug i praksis 1 18-21 korpusskeptikerne 1229 maskinlæsbare 118 metodisk funktion 1211 omfangsbegrænsning 1213 repræsentativitetsproblemet 1 212, 230-232, $15248 f$ sammensætning 1211 spanske 29 269-277 tekstklassifikation 1 217-221 tekstudvalgsprincipper $1233 \mathrm{f}$ tekstypologisering 1 215-217 se også belæg; Brown-Corpus; Freiburger-Korpus; hørekorpora; læsekorpora; Limas-Korpus; LOB-Corpus; Longman Citation Corpus

tekstlingvistik 1 85-95, 15 292, 18 $222 \mathrm{f}$

inferentielle love $\mathbf{1} 88$ retningslinjer globale 30130 (def), $130 f$ lokale 30130 (def) sammenhængslove 189 sammenkædningslove $\mathbf{1} 88$ se også tekstvidenskab tekstning 3 319, 13 235-249

for hørehæmmede 13 241-246 nyheds- 13 235-249

simultan- 13 246-248

staccato- 13248

se også BBC; Danmarks Radio; ear-voice span units; oversættelse; Pariserskolen; simultantolkning; tolkning; transcodage; tvoversættelse; Velotype; voice over

tekstologi

kontrastiv $15291 \mathrm{f}$

tekstpragmatik 1 122f tekstproduktion 1 121-131, 14

238-244

tekstreference 26140 (def)

tekstsekvenser 19 29-50, 44 (def),

20 9-37

i et polyfonisk perspektiv 20 72-76

tekstsemantik 1 124-131

kohærens 1 124-131

tekstsortkonventioner 15290

fagsproglige 15 290-293

tekstsyntaks $1123 \mathrm{f}$

tekstsyntaktisk kohærens $1123 \mathrm{f}$

teksttyper 2 156-163, 14 241f, 20

9-37, 21 (fig), 59-77

argumentative 20 13f, 45-47

i reklamer 20 41-57

beskrivende 2012

vs diskurshandling og tekstgenre

2027 (fig)

forskningen

centrale problemer 20 11-16,

25-35

fortællende $2012 \mathrm{f}$

fremstillende 2013

det illokutionære sigte 2022

instruerende $2014 \mathrm{f}$

J.-M. Adams teori 20 9ff kritik af $2036 \mathrm{f}$

kommunikativ funktion 20 16, 34f og sproglige midler 2033 (fig) teksteksterne og tekstinterne træk 20 81-83

vs tekstgenre og diskurshandling 2027 (fig)

den udsigelsesmæssige forankring 2022

teksttypesekvens 2044 (def)

teksttypologi 20 59-77, 79-104

J.-M. Adams model 20 42, 56, 72

juridisk sprog 20 84-104

ligheder og forskelle 20 92-103

små tekstenheder 20 50-56

tekstvidenskab $1121 \mathrm{ff}$

se også tekstlingvistik

TeleLex 29 339-347 
telicitet $\mathbf{3 5} 218$

tema

-elementer $333 \mathrm{ff}$

fysisk manifestation $334 \mathrm{f}$

adverbial- 3 40-42

nexus- 334

nominal- 3 35-37

fysisk manifestation 3 35-37

sektioner

spansk vs dansk 335

tematisk progression 3 33ff, 21154

tematisk struktur 21154

tema-rema 13258 (def)

oprindelse $13257 f$

struktur 3 29-49

temafokus 13 269-272

temporalt rum 26139

tempus $2153 \mathrm{f}$

som kohæsionsskabende middel

$36173 \mathrm{f}$

termbanker $\mathbf{3 0} 96$

termbaser $\mathbf{3 0} 96$

termer 3 101f, 114f, 118 (def), 18

170 (def)

vs begreber 28158

betydning $\mathbf{3} 115$

ekstension 3115

intension 3115

se også begreber

terminografi 13306 (def), 15191

vs fagleksikografi 13 306-309

se også fagleksikografi

terminologi 3 77f, 99-123, 4 86, 12

159, 15 186-191, 20 269-272, 22

189-192, 28 155-176

-forskning $15186 \mathrm{f}$

i Danmark 15 187-191

begyndelsen 15187

den almene terminologilære $\mathbf{3}$

99-110

grundopfattelse $15188 \mathrm{f}$

kritik af $15188 \mathrm{f}$

arbejdsredskaber 28 169-172

definitionen 494 vs fagleksikografi 13 306-309,

15 191-193

vs fagsprog 3 92-95

vs fagsprogsforskning $15190 \mathrm{f}$

forskningsgenstand $\mathbf{1 5}$ 189f

Handelshøjskolen i København

15187

normativ vs deskriptiv 15189

symposium om 13 305-309

og systemteori 28163

teknisk begrebsdannelse 28 184-187

teori

den abstraktive 28164

klassisk

arbejdsredskaber $28169 f$

Aristoteles' indflydelse 28

158-160

vs nyere strømninger 28155 -

176

den kompositive 28164

positivismens indflydelse $28161 \mathrm{f}$

og systemteori 28 167f

terminologisering 28 184-187

terminologisk leksikografi 13306

som undervisningsfag 15 187, 189

se også begreber; betydning;

definitioner; erhvervssprog; fag-

sprog; sprog; subsprog; teknolekt

termtæthed 14257

that-spor filter 224

TheBrain 3091

Theta-kriteriet 1 169-171

Theta-positioner 1 169-171

Thoiron, Phillipe

videnskabelige tekster 12162

Thom, René

arketypegrafer 19115

arketyper $19118 \mathrm{f}$

kritik af 19119

Thomsen, Christa

forhandlingssprog 2116

Thomsen, K.T.

Dansk-tysk teknisk ordbog (Clau)

1071

tidslogik 5 155f 
tilstandsverber 17 254f, 35 215, 230 titelimperialisme 32203

Toft, Bertha

begrebsrelationer 13305

Genteknologisk ordbog 11 131f

terminologi 22 189-192

og leksikografi 15265

og systemteori 28163

teori og praksis 22192

Toftgaard Andersen, S. ordsprog 3681

vs idiomer 3681

Togeby, Ole

kommatering 13 322, 325

skriftlig fremstilling 14 238-244

talehandlinger 1939

tolkning 11 147-153, 17283 (def)

etik 11150

forskning 17284

Gorbatjov- 11149

hviske- 11149

modersmålsprincippet 11149

som selvstændig disciplin 11153

sprogkombination 11150

tolkeformer 11149

se også ækvivalens; ear-voice span units; Effort-model; oversættelse; Pariserskolen; simultantolkning; tekstning; transcodage

Tomlin, Russ

funktionel grammatik 17141

indhold og udtryk 17162

kommunikation og

informationsbehandling 17166

Tomlinson, C.A.

undervisningsdifferentiering $\mathbf{3 0} 15 \mathrm{f}$

Topdanmark

sprogpolitik 31 148-150

topikalisering, strukturel 27 127-132

topoi 14 162f, 19 115-129, 116f (def)

-kæder 2125

eksplicitering 14162

ekstrinsekke $2125 \mathrm{f}$

elementære 2131

interne 14162 intrinsekke $2125 f$

områder 14162

toposteorien 21 24-26

TopP

vs CP 27 127-132

topstyring 14199

Torres, S.A.

adjektiver og adverbier i spansk $29294 f$

Toulmin, Stephen

argumentationsmodel 2046

Tournay, Joan

et juridisk tekstkorpus 1210

Toury, Gideon

oversættelsesforskning 17283

Traill, E.L.

spanske nominalsyntagmer 29294

transcodage 3190

transparens 14280

transposition 346 (def), 46ff

fakultativ 346

obligatorisk 346

Trier, Jost

feltteorien 287

metaforfelter 18231

Trimble, Louis

fagsprog 313

rhetorical techniques 3 16-18

troncation 356

troper $18220 \mathrm{f}$

Trujillo, Ramón

tempus i grammatikkerne 20278

trunkering $\mathbf{3 0} 86$

TSK $\rightarrow$ tekstsortkonventioner

turn-giving 14215

turn-keeping 14215

turn-taking 14215

i taleenheder

mexikansk og dansk 20149

Tutescu, Mariana

neologismer $1103 \mathrm{f}$

tv-oversættelse $13236 \mathrm{f}$

tværfaglig forskning 36192

tværfaglighed

problemer 36 191-196 
Tversky, Amos

teori om lighed 20 80, 85-87

Tverskys kontrastmodel 2086

tvillingeformler 35154

type coercion $2157 \mathrm{f}$

tyrkisk

turopbygning

vs dansk 20149

tysk

fonetik 15 272-281

fraseologi

dansk-tysk $35155 f$

grammatik 16 252-255

Hochlautung 15275

idiomatik

i moderne dansk-tysk leksiko-

grafi 25 171-199

indikativ

i forretningsbreve 131

vs konjunktiv

i domsudskrifter 133

indirekte tale $125-35$

kommaets funktion og betydning

15287

konjunktiv 1 26-35

metafordomæner i hverdags-

sproget 18 228-237

modusbrug i domme $132-34$

modusbrugen i indirekte tale $\mathbf{1}$

25-35

nominalsyntagmer 15 281-289

assymetri 15282

ordbøger

fremmed-

$$
\text { omvendte } 10154
$$

oversættelse

teknisk

fransk-tysk 35 275-279

passiv 1 63-82

passiverbarhed 1 63-82

litteratur om 170

Tysk-dansk computerordbog med

de engelske fagudtryk

anmeldelse 27 193-200
Tysk-dansk ordbog (Gyld)

anmeldelse 11 155-159

Tysk-dansk/Dansk-tysk ordbog

(Gad)

anmeldelse 13 349f

layout $438 \mathrm{f}$

U

udbytning 14 161, 164

udsagn 2020

udslusningsmekanisme $222 \mathrm{f}$

Ueda, Hiroto

subjektets referenceomfang 29272

Ueda, Yasunari

idiomer 3678

Uggerhøj, Louise

DK87 1234

Ulland, Harald

nominalisering 13359

Ullmann, Stephen

neologismer 1103

semantisk analyse 2104

underlægningsprincippet 1 176-180

undervisning(s) 3021

-differentiering

processorienteret $3015 f$

-rummet 3064 (def)

autonomibegrebet $\mathbf{3 0} 30$ (def)

fjern- 3057 (def), 101-128

se også fremmedsprogsundervis-

ning; læring; sprogundervisning

Undervisningsportalen 3095

unifikationsprincippet 29332

uniformitetsklausulen 27114

universalier

pragmatiske 5116

universalpragmatik $5115 \mathrm{f}$

Unnerup-Madsen, Dorthe

Dansk-Engelsk Handelsordbog

$1070 \mathrm{f}$

uptaking $14215 \mathrm{f}$

URL-søgning 3082

usus imperans 2198

usus imperium 
138

vs usus tyrannus 21 99-104 usus tyrannus

vs usus imperium 21 99-104

UVVU 34 265-278

V

Vagn Jensen, H.

skriftlig fremstilling 14 238-244

valens

-mønstre og sætningsmønstre 17

158-161

entitet 17 156-159

instigator 156 (def), 17 156-159

semantisk 1 71-76

syntaktisk 171

verbets 2149

Valentin, Paul nominalgrupper i tysk $15281 \mathrm{ff}$

Varela, Fernando

Diccionario Fraseológico del

Español Moderno 17 266-268

Vater, H.

koordinerede determinativfraser

15286

tyske nominalfrasers assymetri 15 282

Vater, Pia

Spansk-dansk ordbog (Gyld) 26 151-163

vederhæftighedskravet 5118

Veiga, Alexandre

konjunktiv og indikativ i spansk 20279

Velotype $13246 f$

vendinger 35109

venstrerestriktion 219

verbaler 20107 (fig)

verbalmodel 35 216-218, 217 (fig)

figurer

primære $35217 \mathrm{ff}$

sekundære $35217 \mathrm{ff}$

verber

aktionsarts- 35230

aktivitets- $\mathbf{3 5}$ 215, 231 ambivalente 35222

argumenter 2149 (def)

aspekt 35230

begynde/beginnen 29 53-62

bevægelses- 35212

broverbumsfænomener 2 21-26, 30

fase- 2960 (def)

semantisk beskrivelse 29 53-69

tidsbetingelse 29 53-69

genus 35 215f, 230

handlings- 17 254f, 35 215, $231 \mathrm{f}$

IMAGE-IDEA-PAIRS 35 216-219

klasser $35215 f$

komplekse 35215

leksikaliseringsmønstre 35 211-236

modal- 1 133-150

engelsk og dansk 1 133-150

objektivistiske

explicit 176

implicit 176

oldrussisk

flertydige 35213

genus $35219 f$

det verbale leksikon 35 219-229

proces- $17254 \mathrm{f}$

sekundære verbalkategorier 21

53-56

sekvenser 14204

spansk 20 277-280

imperfecto 17 253-255

indefinido 17 253-255

tempora i fortid indikativ 17

251-255

verbet caer's semantik 29273

strukturer 320

symmetriske $35223 \mathrm{f}$

temporalitet 17152 (def)

tilstands- 17 254f, 35 215, 230

transitivitet 35230

valens 2149

verdiktiver 5114

Vergnaud, Jean R.

kasus 1172

veridiktion 13256 (def), 256f

verificering 
interpersonel 3113

Verum-Fokus 13267

Vibæk, Marius

erhvervssproglig forskning 21140

Vidal, M.V.E.

nominalsyntagmer 17 239-243

viden

encyklopædisk $285 \mathrm{f}$

factual absurdity $285 \mathrm{f}$

fag- 14253

knowledge-telling $14205 \mathrm{f}$

knowledge-transforming $14205 f$

linguistic absurdity $285 \mathrm{f}$

sproglig $285 \mathrm{f}$

videnskab

idiografisk 14255

nomothetisk 14255

videnskabelig uredelighed 34 265-

278, 268 (def)

eksempler 34 271-276

generelle kriterier 34 267-271

inden for lingvistik $34272 \mathrm{ff}$

vs selektiv videnskab 34 272-274

vidensteknik

symposium om 13 305-309

Vigsø, Orla

anmelderi 19135

strukturalisme 31 211-213

Vikner, S.

ekspletive udtryk 27121

Vinay, J.P.

substantivsyntagmer $\mathbf{3} 38$

transposition 346

Vinogradov, V.V.

sprogfunktioner 1202

stilistik 1 198ff

virkelighed 13253 (fig)

virksomhedskommunikation 27

139-166

autoritet 27148

distance 27148

og systemisk funktionel lingvis-

tik 34 143-166

virksomhedspræsentationer 27

139-166 den horisontale relation 27

149-159

den vertikale relation 27 159-165

Virtanen, Tuija

teksttyper 2053

voice over 13247

vokativ 26120 (def)

kendetegn

semantiske, syntaktiske og

formalsproglige 26 120-122

markeret/umarkeret brug 26124

pragmatiske funktioner 26 125-134

spansk

i pragmatisk-funktionelt per-

spektiv 26 119-135

VOX/Universidad de Alcala de

Henares Diccionario para la

enseñanza de la lengua española anmeldelse 17 268-272

VP-autorisationsprincippet 1 171f

Vrang, Vibeke

Dansk-hollandsk ordbog 20200

Den Danske Ordbog 33 179-191

Vuillaume, M.

nominalgrupper $15281 \mathrm{ff}$

Vulgata 5 24, 26

\section{W}

Walther, Giesela

passivforskningen 1 68-69

Warschauer, Mark

CALL 3013

web 3082

-dokumenter $3087 \mathrm{f}$

vs Internet $\mathbf{3 0} 82$

usynligt $\mathbf{3 0} 82$

WebCorp 3097

Weilgaard, Lotte

metal-ordbøger 13305

Weinrich, Harald

litteraturens lingvistik 2017

metaforfelter 18231

Weisgerber, L.

feltteorien 287 
Weiss, S.

international forhandling 2190

Wenche, Vagle

radiosproget 6 189-193

Werlich, E.

teksttyper 20 60-67

Werner, Reinhold idiom-markering i ordbøger 25 176, 180

Werther, Charlotte europæisk integration og identitet 13347

Wh-flytning 1 154ff, 2 16-26 succesiv cyklisk COMP-til-COMP 2 21-26

Wichmann, K.K. sprogpolitik 31 167-170

Widdowson, Henry notions 318

scientific discourse 314

Wiegand, H.E.

alordbog 268

encyklopædiske angivelser i ordbøger $2926 \mathrm{f}$

fagtekstuel kohærens 148 fraseologi/idiomatik

kontrastive normer 25192

i ordbøger 25199

leksikografiske værker $21122 \mathrm{f}$

ordbogens ydre selektion 25193

termen begreb 13305

udnævnelse til æresdoktor 20181

Wierzbicka, Anna

begrebet begreb 391

encyklopædiske angivelser i ord-

bøger $2926-28$

fagsprog 487

sememer 293

Wijst, P. van der

høflighedsstrategier 2190

wildcards $\mathbf{3 0} 86$

Wildgen, Wolfgang

arketypegrafer 19115

Wilken, Lisanne

folkelingvistik 36195 nation, kultur og sprog i Europa

36183

Wilkins, D.A.

sprogindlæringsmodeller 3 11, 13

Williams, Edwin

begrænsende knuder 230

kasus 1172

Wittgenstein, L.

spil 26139

sprog og begreb $28163 \mathrm{f}$

stærk antirepræsentationalisme

2140

terminologi 28164

veridiktion og monstration 13257

Wittgensteins kaninand 2937 (fig)

se også Rubins profilvase

Words and Phrases, Legally Defin-

ed 2 56ff

Wortfeld 287

Wotjak, Gerd

spansk

substantiver og adjektiver 29

290-299

verber 20 277-280

Wüster, Eugen

begreb 3100

vs term $\mathbf{2 8} 158$

fagsprog $379 f$

vs almensprog 28161

terminologi $\mathbf{3}$ 92, 15189

$\mathbf{X}$

X-bar-syntaks 1 159-161

X-spørgsmål 1939

xenismer $\rightarrow$ lån

xenofrasemer 32 206, 215f

XP-udtryk

kategorisering 27 90-99

semantik 27 93f

syntaks 27 90-99

funktioner 27 111-120 
$\mathbf{Y}$

Yahoo 3080

Yourdictionary 3094

ytringer 13 257-259, 264, 14 172-178

informationsstruktur

på sætnings-/ytringsniveau 13

251-278

uden fokus 13264

ytringssituationer 14 172-178, 183f,

21 59-63, 59 (fig)

$\mathbf{Z}$

Zahle, Henrik

videnskabelig uredelighed 34270

zapadnikker 6204

zeugma 362244

Zint, Ingeborg

Dansk-tysk ordbog. Undervisning grammatik i 12 209f

Zoëga, Anne

tolkning 15268

Zürcherbibelen 517 


\section{Add dimension \\ to yourr \\ sociology \\ research --

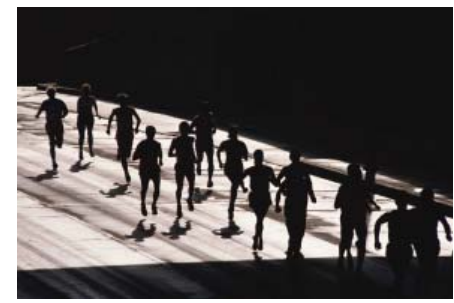 \\ CSA Sociological Abstracts}

Comprehensive, cost-effective, timely coverage of current ideas in sociological research

Abstracts of articles, books, and conference papers from nearly 2,000 journals published in 35 countries;

citations of relevant dissertations as well

Now featuring:

- Cited references

as books and other media.

- Backfiles to 1952

- Scholar profiles

Now available with ProQuest Full-Text!

Contact sales@csa.com for trial Internet access or a sample issue

\section{CSA Sociological Abstracts Discovery Prize}

Promoting teaching and learning in the social sciences through the use of CSA Sociological Abstracts

Entry information and past winners: info.csa.com/sociologicaldiscovery

\section{Pro Guest CSA}

